Article

\title{
Irrigation with Coal Mining Effluents: Sustainability and Water Quality Considerations (São Pedro da Cova, North Portugal)
}

\author{
Catarina Mansilha ${ }^{1,2, *(\mathbb{D}}$, Armindo Melo $\left.{ }^{1,2} \mathbb{(}\right)$, Deolinda Flores ${ }^{3,4}\left(\mathbb{D}\right.$, Joana Ribeiro ${ }^{3,5}$, João Ramalheira Rocha ${ }^{4}$, \\ Vítor Martins ${ }^{4}$, Patrícia Santos ${ }^{3,4}$ (D) and Jorge Espinha Marques ${ }^{3,4}$ (D) \\ 1 National Institute of Health Doutor Ricardo Jorge, Department of Environmental Health, University of Porto, \\ 4050-083 Porto, Portugal; armindo.melo@insa.min-saude.pt \\ 2 LAQV/REQUIMTE, Associated Laboratory for Green Chemistry of the Network of Chemistry and \\ Technology, University of Porto, 4050-083 Porto, Portugal \\ 3 Institute of Earth Sciences, Porto Pole, University of Porto, 4169-007 Porto, Portugal; dflores@fc.up.pt (D.F.); \\ joana.ribeiro@uc.pt (J.R.); patricia.santos@fc.up.pt (P.S.); jespinha@fc.up.pt (J.E.M.) \\ 4 Department of Geosciences, Environment and Spatial Planning, University of Porto, 4169-007 Porto, Portugal; \\ up201206901@fc.up.pt (J.R.R.); up199702778@fc.up.pt (V.M.) \\ 5 Department of Earth Sciences, University of Coimbra, 3030-790 Coimbra, Portugal \\ * Correspondence: catarina.mansilha@insa.min-saude.pt
}

\section{check for} updates

Citation: Mansilha, C.; Melo, A.; Flores, D.; Ribeiro, J.; Rocha, J.R.; Martins, V.; Santos, P.; Espinha Marques, J. Irrigation with Coal Mining Effluents: Sustainability and Water Quality Considerations (São Pedro da Cova, North Portugal). Water 2021, 13, 2157. https:// doi.org/10.3390/w13162157

Academic Editor: William Frederick Ritter

Received: 21 June 2021

Accepted: 31 July 2021

Published: 5 August 2021

Publisher's Note: MDPI stays neutral with regard to jurisdictional claims in published maps and institutional affiliations.

Copyright: (c) 2021 by the authors. Licensee MDPI, Basel, Switzerland. This article is an open access article distributed under the terms and conditions of the Creative Commons Attribution (CC BY) license (https:// creativecommons.org/licenses/by/ $4.0 /)$.

\begin{abstract}
Two water effluents that drain from the abandoned coal mine of São Pedro da Cova (NW Portugal) were characterized in terms of their physic-chemical properties and suitability for irrigation purposes. Samples were also collected in a local surface stream, upstream and downstream from the mine drainage points, also used for irrigation by local farmers. Water samples were analyzed for major and minor ions and for trace element concentrations. Sampling campaigns started in 2017 and ended in 2019 and there were 46 water quality parameters tested. There were also proposed allinclusive indices (the Water Quality Index and the Contamination Index, and also the Trace Element Toxicity Index) based on specific groups of 18 and 17 physic-chemical parameters, respectively, to achieve adequate monitoring requirements for mine effluents and surface water from coalfield. From the physical and chemical aspects of mine water it is inferred that the mine is not producing acid mine drainage. The coal mine water is of medium to high salinity, having almost neutral $\mathrm{pH}$ and a high thermal stability during the year, which is a distinguishing feature of the effluents. When compared to international irrigation water quality standards, as Food and Agriculture Organization of the United Nations admissible concentrations, the impacted waters are unsuitable for irrigation. The major outliers to the guidelines were iron, manganese, potassium, magnesium and bicarbonates, being also detected carcinogenic polycyclic aromatic hydrocarbons. Cost-effective ways of monitoring water quality parameters are needed to help control and manage the impact of coal mine effluents that should be treated before releasing into a ditch system that could be then used by local farmers to irrigate their crops.
\end{abstract}

Keywords: coal mine wastewater quality; irrigation; heavy metals; water quality index; environmental impact

\section{Introduction}

Irrigation is fundamental for agriculture but policies that push towards a restrained use of water are not popular among farmers, who are also not prepared to respond to drastic increases in water costs, which could decrease the economic profitability of their activities. Therefore, the use of unconventional free water sources, such as mine wastewaters, is regarded as a possible choice for irrigation. Effluents from coal mines are often considered severe and persistent forms of pollution, with environmental impact not only throughout the mine's life cycle, but also long after the end of mining activities. Some deleterious impacts on the environment include the disruption of hydrological pathways, 
contamination of surface and groundwater, depression of the water table, soil contamination and loss of biodiversity [1,2]. The concentration of contaminants in coal mine drainage waters vary greatly and depends on a series of geological, hydrological and mining conditions, which are different from mine to mine. Therefore, the effluents can be alkaline, acidic, ferruginous, highly saline, or even clean [3]. Frequently, coal mine drainage is acid metal-rich waters with high concentrations of iron $(\mathrm{Fe})$, copper $(\mathrm{Cu})$, manganese $(\mathrm{Mn})$ and nickel $(\mathrm{Ni})$, formed during water-rock interaction involving sulfur-bearing minerals, such as pyrite $\left(\mathrm{FeS}_{2}\right)$. These processes may cause red, orange, or yellow sediments with negative impacts on ecosystems and water resources. Additionally, mine effluents often contain high levels of total dissolved and suspended solids. The dissolved cations include mainly calcium $(\mathrm{Ca})$, magnesium $(\mathrm{Mg})$, sodium $(\mathrm{Na})$ and potassium $(\mathrm{K})$; the major anions are sulfate $\left(\mathrm{SO}_{4}\right)$, chloride $(\mathrm{Cl})$, fluoride $(\mathrm{F})$, nitrate $\left(\mathrm{NO}_{4}\right)$, bicarbonate $\left(\mathrm{HCO}_{3}\right)$ or carbonate $\left(\mathrm{CO}_{3}\right)$ [4].

The Douro Coalfield (NW Portugal) represents the most important coal-bearing deposit in Portugal [5-8] with $53 \mathrm{~km}$ length and width between 30 and $250 \mathrm{~m}$ (Figure 1).

São Pedro da Cova mining area was one of the principal centers of mining activity in Portugal (Figure 2a,b), with great economic and technological impacts, and a cultural significance from the end of the 17th century (1795), until the 20th century (1970) [9].

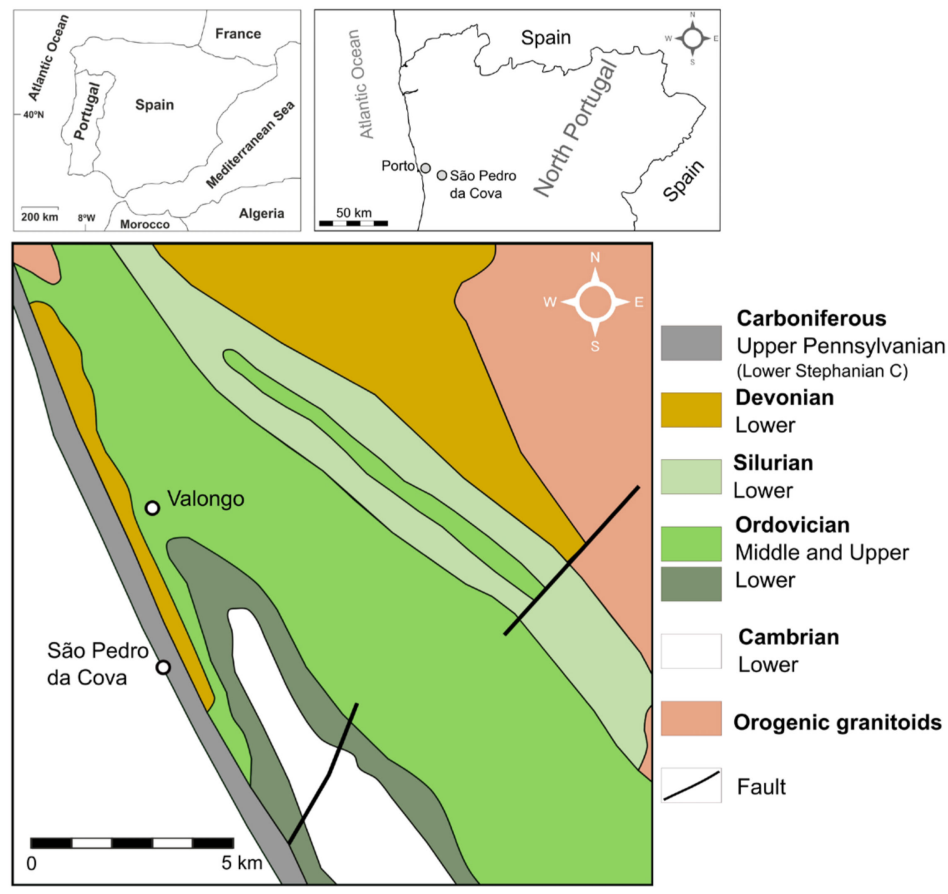

Figure 1. Some aspects of the study area: (a) São Pedro da Cova mine in the mid 20th century; (b) São Pedro da Cova mine in 2021; (c) Silveirinhos stream upstream from the mining effluents discharge; (d) mining effluents discharge; (e) water monitoring in Silveirinhos stream downstream from the mining effluents discharge; (f) irrigation with polluted water from Silveirinhos stream; (g) agricultural area irrigated with polluted water from Silveirinhos stream.

The São Pedro da Cova coal mine is an abandoned mine located in a peri-urban area, with a landscape consisting of a mosaic of urban, industrial, agricultural and forest areas (Figure 2a,b). The mine is located very close to a densely populated zone with several basic facilities including schools, a healthcare center and a leisure center.

The coal mining effluents from two mine drainage galleries are discharged around $1 \mathrm{~km}$ to SE of the mine, producing an ocher-colored sediment that is continuously accumulated in local watercourses (Silveirinhos stream and Ferreira river). Water from Silveirinhos stream is collected downstream from the mine drainage discharges and is locally used for agriculture irrigation. Local farmers have been using this polluted water for decades to 
produce a wide variety of products, including green vegetables, corn, barley and fruits (Figure 2c-g).

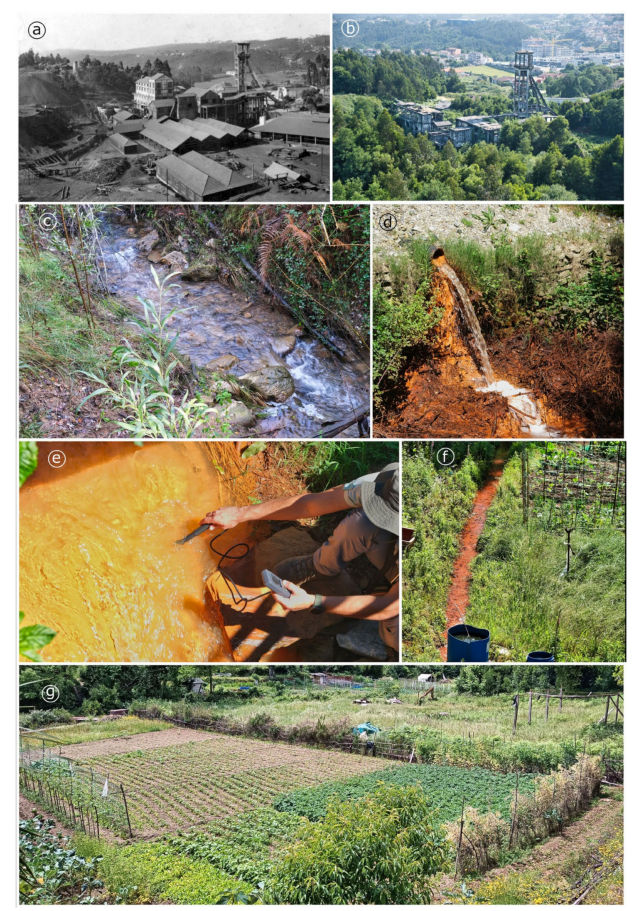

Figure 2. São Pedro da Cova location and geological setting (modified from [10]).

This study aimed at assessing the impact of coal mining effluents on the quality of irrigation water, by means of water quality individual parameters and indices.

This approach intended to contribute to the development of a specific evaluation methodology for coal mining regions in terms of i) the suitability of this type of water for irrigation purposes and ii) the environmental impacts resulting from the uncontrolled applications of these unconventional water resources in irrigated areas.

\section{Assessment of Irrigation Water Quality: A Short State of the Art}

Mine effluents are used for irrigation purposes worldwide, as they constitute an easily accessible and inexpensive source of water.

The quality of irrigation water is considered a key factor for safe food production [11]. However, when good quality water is scarce, water of marginal value is often considered for use in agriculture [12]. The prolonged and uncontrolled use of polluted water could result in reduced crop yields, deterioration of soil properties and severe environmental and health damages, requiring more complex management practices and more stringent monitoring procedures [13]. Therefore, the agricultural use of water resources in areas affected by mining activities requires not only a baseline water quality data, but also continuous monitoring.

There are several quality standards and guidelines for irrigation water proposed by various countries and organizations, combining conservative and liberal approaches. However, despite being useful, they are not always satisfactory due to the wide variability of hydrological and hydrogeological settings [14-17].

In 1985, the Food and Agriculture Organization of the United Nations (FAO) published a document concerning water quality for agriculture, which was reprinted in 1994, presenting a set of guidelines modified to give more practical procedures for evaluating and managing water quality-related problems, emphasizing long-term effects [18]. These general water quality classification guidelines help identify potential crop production problems associated with the use of conventional water sources, and are equally applicable to evaluate wastewaters for irrigation purposes in terms of their chemical constituents. 
As wastewater effluents may contain a number of toxic compounds, FAO also presented threshold levels for some selected trace elements.

FAO's guidelines have been widely incorporated into national regulations all over the world and the following criteria have been considered the most relevant in defining quality $[13,15,18]$ :

(i) Salinity hazard: the concentration of soluble salts in irrigation water, estimated in terms of electrical conductivity. Salinity has been deemed as the most important factor of irrigation water quality because high salinity in soil can create a hostile environment for the crop to absorb nutrients and cause specific ion toxicity;

(ii) Infiltration and permeability problems: the two most common water quality factors which influence the normal infiltration rate are water salinity (total quantity of salts in the water) and the sodium content relative to the calcium and magnesium content;

(iii) Specific toxicity hazard: certain ions and metals can accumulate in sensitive crops in concentrations high enough to cause damage and reduce yields. The ions of primary concern are boron, sodium and chloride;

(iv) Miscellaneous effects: these include high nitrogen concentrations in water, which supplies nitrogen to the crop and may cause excessive vegetative growth, lodging and delay crop maturity; unsightly deposits on fruit or leaves due to overhead sprinkler irrigation using water with high bicarbonate, gypsum, or iron contents; various abnormalities often associated with an unusual water $\mathrm{pH}$.

In order to better classify water based on its specific characteristics and possible uses, a number of models of water quality, named Water Quality Indices (WQI), have also been developed since the 60s [19]. WQI are simplified representations of complex realities, used to assess the suitability of water for certain purposes based on specific characteristics. The use of WQI allows the representation of a large number of parameters in a single numerical value, facilitating the operational management of water resources and their allocation for different uses [20]. However, for this number to accurately represent the reality of a water body, the correct selection of environmental quality parameters is essential [21].

The first modern WQI was proposed by Horton (1965) [22] and was followed by numerous studies in this field. In recent years, many modifications have been considered in the WQI concept and several indices have been proposed and used by governmental agencies and researchers $[19,20,23]$.

Misaghi et al. (2017) [24] introduced the first systematic WQI for irrigation purposes. However, this index considers a limited set of parameters for estimating water quality and does not take into account all potential impacting properties that could be critical, especially regarding wastewaters or other "marginal" quality waters.

The selection of variables is of major importance in calculating WQI as they should be independent and the most relevant ones, in order to define water quality and detect water quality deterioration. Several indices use parameters selected according to the opinion of specific expert panels, and the consequence is that the final evaluation can be highly subjective and variable. Other authors propose that the selection of parameters should be made according to the water management objectives, the location of the studied waters and the sampling periodicity [20].

To assess the impact of mining activities on irrigation water, some indices seemed to be more appropriate than others to be used as additional tools, as the Weight Arithmetic Water Quality Index method (WQI ${ }_{\mathrm{A}}$ ), proposed by Cude (2001) [25], which is based on Horton's principles but has been modified by introducing the normative values of the major factors of the water [20,25], the Contamination Index (CI), developed by Backman et al. (1998) [26-28] and the Trace Element Toxicity Index (TETI), by Ali et al. (2017) which is based on contaminant hazard intensity [28].

Furthermore, despite the usefulness and importance of normative guidelines, the effect of unusual or special water constituents is not always considered. An example is the contamination by polycyclic aromatic hydrocarbons (PAH), which are persistent, semi-volatile organic pollutants that can result from the oxidation and self-combustion 
of mine wastes and should be analyzed in mining surroundings due to their genotoxic, mutagenic and carcinogenic properties [29]. Although there are many PAHs, scientists and regulators have focused on 16 compounds that have been identified as priority control pollutants by the U.S. Environmental Protection Agency (USEPA). PAHs in underground mining environments may dissolve in mine water and eventually pollute the groundwater system. In addition, mine effluents can bring PAHs to the surface environment, polluting surface water and soils as well [30].

\section{Materials and Methods}

\subsection{Study Area}

The region of São Pedro da Cova (N 41 $09^{\prime}$; W $\left.8^{\circ} 30^{\prime}\right)$ is situated in NW Portugal (Figure 1), in the city of Porto peri-urban region and has a resident population of around 16,500 inhabitants [31] and an area of $16 \mathrm{~km}^{2}$, where the territory comprises residential, industrial, and agroforestry areas (Figure 2a,b,g).

The region is located in the Central-Iberian Zone of the Iberian Massif [32]. The regional geological units consist of metasedimentary rocks (Figure 1) with minor sedimentary cover areas. For that reason, the prevailing groundwater circulation media are fractured.

The study region is located along the western limb of the Valongo Anticline, a regional megastructure [33], which created mountainous landforms reaching 367 and $385 \mathrm{~m}$ of altitude at the Santa Justa and Pias summits, respectively, on its western and eastern flanks. The regional morphology is dominated by two hill alignments that originated from differential erosion and are crosscut by Douro River. This structure controlled significantly the regional drainage network, that is part of the Douro river. In São Pedro da Cova it is possible to identify different metasedimentary formations with ages between the Precambrian and/or Cambrian, Ordovician, Silurian, Devonian and Carboniferous.

The old mine of São Pedro da Cova, where exploitation of anthracite A occurred for nearly 200 years, is located in one of the multiple coal deposits hosted in Douro Coalfield (from Upper Pennsylvanian), that represents the most significant Portuguese coal-bearing deposit. This deposit is elongated along NW-SE, presenting an approximate length of $53 \mathrm{~km}$ and variable width, ranging from 30 to $250 \mathrm{~m}$. The sedimentary sequence comprises a basal breccia, followed by fossiliferous shales, siltstones and sandstones, along with interlayered conglomerates and coal seams [10].

The regional climate is Atlantic, the normal annual precipitation is around $1254 \mathrm{~mm}$ (with $195 \mathrm{~mm}$ in December and $18 \mathrm{~mm}$ in July) and the normal annual air temperature is around $15^{\circ} \mathrm{C}$ (with $20^{\circ} \mathrm{C}$ in July and August and $9^{\circ} \mathrm{C}$ in January). The Köppen-Geiger climate classification is $\mathrm{Csb}$ : warm temperate, with dry and warm summers $[34,35]$.

\subsection{Water Sampling}

Groundwater samples were collected from two mine drainage galleries (G1 and G2). Additionally, surface water from Silveirinhos stream was sampled in two points, one located upstream (SS-U) and the other downstream (SS-D) from the mine galleries discharge (Figure 2d). Nine sampling campaigns were carried out in two periods, from April 2017 until December 2017 (Apr, Jun, Sep, Dec 2017), and from November 2018 until December 2019 (Nov 2018; Feb, May, Sep, Dec 2019), in a total of 34 samples. In the campaigns of October 2017 and September 2019 it was not possible to collect water from Silveirinhos stream upstream from the drainage galleries because, during the dry season, this part of the stream does not flow.

The sampling points were chosen in order to be preserved from other anthropogenic impacts besides coal mining, reducing the risk of water contamination by other pollution sources. Sampling was carried out according to standard methods: ISO 5667-3:2018 (E) Water quality-Sampling-Part 3 [36]. Samples were collected in glass or polyethylene bottles, were stored at low temperature $\left(<5^{\circ} \mathrm{C}\right)$ in the dark, and delivered to the laboratory within $5 \mathrm{~h}$. The samples were collected with as little agitation or disturbance as possible. Special preservatives were required for some parameters. In this case, care was taken not to 
flush any preservative out of the bottle during sampling. Conditions such as strong winds or heavy rain were avoided during sampling.

Water samples were analyzed for a range of physical and chemical constituents in the laboratory, while temperature, $\mathrm{pH}$ and $\mathrm{EC}$ were measured in situ at the moment of sampling (Figure 2e), using a multiparametric meter from Hanna Instruments, model HI-991300, Woonsocket, RI, USA.

This set of sampling points provided a monitoring network for investigating the impact of mine drainage on environment, namely on irrigation water chemistry, including its seasonal variation.

\subsection{Laboratory Analysis}

Analyses were performed according to procedures outlined in Standard Methods for the Examination of Water and Wastewater 23rd edition [37] and in Le Rodier-L'analyse de l'eau $10^{\mathrm{e}}$ édition [38]. The laboratory has been accredited under ISO/IEC 17025 since 2007. Precision and accuracy were calculated for all analytical methods with values $<10 \%$. Uncertainties were also calculated with results varying from $2 \%$ to $10 \%$.

Water turbidity was measured in a Hach 2100N Laboratory Turbidity Meter (Hach Lange, Düsseldorf, Germany). Electrical conductivity (EC) and $\mathrm{pH}$ were determined in a Crison MultiMeter MM 41 (Hach Lange Spain, S.L.U., Barcelona, Spain). Total alkalinity, carbonates $\left(\mathrm{CO}_{3}{ }^{2-}\right)$ and bicarbonates $\left(\mathrm{HCO}_{3}{ }^{-}\right)$, were analyzed by titration. Phosphate $\left(\mathrm{PO}_{4}{ }^{2-}\right)$ was analyzed in a Shimadzu UV-1601 Spectrophotometer (Shimadzu Corporation, Kyoto, Japan). Chemical oxygen demand (COD) was evaluated in a Hach DR 2800 Spectrophotometer (Hach Company, Loveland, $\mathrm{CO}, \mathrm{USA})$. Major inorganic ions $\left(\mathrm{Na}^{+}\right.$, $\mathrm{K}^{+}, \mathrm{Mg}^{2+}, \mathrm{Ca}^{2+}, \mathrm{Li}^{+}, \mathrm{Cl}^{-}, \mathrm{NO}_{3}{ }^{-}, \mathrm{F}^{-}$and $\mathrm{SO}_{4}{ }^{2-}$ ) were analyzed by ion chromatography (DionexTM system DX-120/ICS-1000, Dionex Corporation, Sunnyvale, CA, USA). Total organic carbon (TOC) was analyzed in a Shimadzu TOC-V (TOC-ASI-V, Shimadzu Corporation, Kyoto, Japan), heavy metals $(\mathrm{Cr}, \mathrm{Mn}, \mathrm{Ni}, \mathrm{Cu}, \mathrm{Zn}, \mathrm{As}, \mathrm{Cd}$ and $\mathrm{Pb}$ ) and other components, such as $\mathrm{Al}, \mathrm{Fe}, \mathrm{NO}_{2}{ }^{-}, \mathrm{NH}_{4}{ }^{+}$and $\mathrm{SiO}_{2}$ were analyzed in a Varian AA240 Atomic Absorption Spectrometer (Varian Inc., Palo Alto, CA, USA) and in a Continuous Segmented Flow Instrument (San-Plus Skalar, Skalar Analytical, Breda, The Netherlands), respectively. PAHs were analyzed by dispersive liquid-liquid microextraction coupled to gas chromatography/mass spectrometry (DLLME-GC/MS) methodology in a Shimadzu GCMS-QP2010 gas chromatograph mass spectrometer equipped with an auto injector AOC5000 (Shimadzu Corporation, Kyoto, Japan), according the procedure described in Borges et al. 2018 [39].

Analytical standards were supplied by Sigma-Aldrich (Steinheim, Germany) and Merck (Darmstadt, Germany). The reference standard mixture containing the 16 EPA PAHs (naphthalene, Nap; acenaphthylene, Acy; acenaphthene, Ace; fluorene, Flu; phenanthrene, Phe; anthracene, Ant; fluoranthene, Flt; pyrene, Pyr; benz[a]anthracene, BaA; chrysene, $\mathrm{Chr}$; benzo[b]fluoranthene, $\mathrm{BbF}$; benzo[ $k]$ fluoranthene $\mathrm{BkF}$; benzo[a]pyrene, $\mathrm{BaP}$; dibenz $[a, h]$ anthracene, DahA; benzo[ghi]perylene, BghiP; and indeno[1,2,3-cd]pyrene, Ind) was purchased from Sigma-Aldrich (Steinheim, Germany).

Methanol, dichloromethane and acetonitrile were organic trace analysis grade SupraSolv and were supplied by Merck (Darmstadt, Germany). Ultrapure water was highly purified by a Milli-Q gradient system $(18.2 \mathrm{~m} \Omega / \mathrm{cm})$ from Millipore (Milford, MA, USA).

\subsection{Irrigation Water Quality Parameters}

Water quality evaluation is necessary to assess the suitability of water to serve a specific purpose, and to determine appropriate treatments or precautions, if necessary. However, monitoring all parameters involved in a water source could be time-consuming and expensive. Therefore, reducing the subjectivity and the effective cost for assessing water quality is a great challenge.

This study focuses on the parameters adopted by FAO guidelines 29 [18] and on a set of quantitative assessment ratios which included the widely applied Sodium Adsorption 
Ratio (SAR), the Total Hardness (TH), the Residual Sodium Carbonate (RSC) and the Permeability Index (PI) (Table 1).

Table 1. Water quality classification as per different water quality ratios/parameters.

\begin{tabular}{|c|c|c|c|}
\hline Parameter & & Categories & Ranges \\
\hline Sodium Adsorption Ratio (SAR) [40] & $\mathrm{SAR}=\frac{\mathrm{Na}^{+}}{\sqrt{\left(\mathrm{Ca}^{2+}+\mathrm{Mg}^{2+}\right) / 2}}$ & $\begin{array}{l}\text { - Excellent } \\
\text { - Good } \\
\text { - Doubtful } \\
\text { - Unsuitable }\end{array}$ & $\begin{array}{c}<10 \\
10-18 \\
18-26 \\
>26\end{array}$ \\
\hline Total Hardness (TH) [41] & $\mathrm{TH}=\left(\mathrm{Ca}^{2+}+\mathrm{Mg}^{2+}\right) \times 50$ & $\begin{array}{l}\text { - Soft } \\
\text { - Moderately hard } \\
\text { - Hard } \\
\text { - Very hard }\end{array}$ & $\begin{array}{c}<75 \\
75-150 \\
150-300 \\
>300\end{array}$ \\
\hline Residual Sodium Carbonate (RSC) [40] & $\begin{array}{c}\mathrm{RSC}=\left(\mathrm{CO}_{3}^{2-}+\mathrm{HCO}_{3}^{-}\right)- \\
\left(\mathrm{Ca}^{2+}+\mathrm{Mg}^{2+}\right)\end{array}$ & $\begin{array}{l}\text { - Good } \\
\text { - Medium } \\
\text { - Not suitable }\end{array}$ & $\begin{array}{c}<1.25 \\
1.25-2.5 \\
>2.5\end{array}$ \\
\hline Permeability index (PI) [42] & $\mathrm{PI}=\frac{\mathrm{Na}^{+}+\sqrt{\mathrm{HCO}_{3}^{-}}}{\mathrm{Ca}^{2+}+\mathrm{Na}^{+}+\mathrm{Mg}^{2+}} \times 100$ & $\begin{array}{l}\text { - Class I } \\
\text { - Class II } \\
\text { - Class III }\end{array}$ & $\begin{array}{l}>75 \\
25-75 \\
<25\end{array}$ \\
\hline
\end{tabular}

Moreover, in order to meet the hydrogeological and hydrogeochemical specificity of coal mining effluents, the water quality indices $\mathrm{WQI}_{\mathrm{A}}, \mathrm{CI}$ and TETI were considered of significant importance and, therefore, were also calculated.

The water quality index based on the weighted arithmetic method $\left(\mathrm{WQI}_{\mathrm{A}}\right)$ was amended to be specific for irrigation, being adjusted taking into consideration the FAO recommendations, that is, the weights were defined as functions of the standards proposed in this guideline. For computation of the $\mathrm{WQI}_{\mathrm{A}}$ index, 18 water quality parameters were used, namely, the EC to estimate the salinity hazard; 3 elements with specific ion toxicity $\left(\mathrm{Na}^{+}, \mathrm{Cl}^{-}\right.$and B); 3 elements with miscellaneous effects $\left(\mathrm{NO}_{3}{ }^{-}, \mathrm{HCO}_{3}{ }^{-}\right.$and $\left.\mathrm{pH}\right)$ and 11 trace elements with Recommended Maximum Concentration Values $\left(\mathrm{Al}^{3+}, \mathrm{As}, \mathrm{Cd}^{2+}\right.$, $\mathrm{Pb}^{2+}, \mathrm{Cu}^{2+}, \mathrm{Cr}^{3+}, \mathrm{Fe}^{2+}, \mathrm{Mn}^{2+}, \mathrm{Ni}^{2+}, \mathrm{Zn}^{2+}$ and $\mathrm{F}^{-}$).

WQIA was calculated by using the following equation $[20,43,44]$ :

$$
\mathrm{WQI}_{\mathrm{A}}=\sum_{\mathrm{i}=1}^{\mathrm{n}} \mathrm{Q}_{\mathrm{i}} \mathrm{W}_{\mathrm{i}} / \sum_{\mathrm{i}=1}^{\mathrm{n}} \mathrm{W}_{\mathrm{i}}
$$

The quality rating scale $\left(\mathrm{Q}_{\mathrm{i}}\right)$ for each parameter for a total of $n$ water quality parameters is calculated by using this expression:

$$
\mathrm{Qi}=100\left[\left(\mathrm{~V}_{\mathrm{i}}-\mathrm{V}_{0} / \mathrm{S}_{\mathrm{i}}-\mathrm{V}_{0}\right)\right]
$$

where, $\mathrm{V}_{\mathrm{i}}$ is the actual value of the ith water quality parameter obtained from laboratory analysis, $V_{0}$ is the ideal value of that water quality parameter obtained from standard Tables $\left(\mathrm{V}_{0}=0\right.$, except for $\left.\mathrm{pH}=7.0\right)$ and $S_{i}$ is the recommended standard value of ith parameter.

The relative unit weight $\left(\mathrm{W}_{\mathrm{i}}\right)$ for each water quality parameter is calculated by adopting the following formula:

$$
\mathrm{W}_{\mathrm{i}}=\mathrm{K} / \mathrm{S}_{\mathrm{i}}
$$

where, $\mathrm{K}$ is the proportionality constant and can also be calculated by using the following equation:

$$
\mathrm{K}=\frac{1}{\sum_{\mathrm{i}=1}^{\mathrm{n}}\left(1 / \mathrm{S}_{\mathrm{i}}\right)}
$$


The proposed index ranges from 0 to 100 and plain descriptions for index data were developed in order to provide a qualitative description of the index outcome [44,45]. The calculation of WQI ${ }_{\mathrm{A}}$ following the 'weighted arithmetic index method' involves the estimation of 'unit weight', assigned to each physic-chemical parameter considered for the calculation. By assigning unit-weights, all the concerned parameters of different units and dimensions are transformed to a common scale.

Weightage of each parameter means its relative importance in the overall water quality, and it depends on the permissible limits. Those parameters which have low permissible limits and can influence water quality to a large extent allocate high weighting, while parameters having high permissible limits are less harmful to the water quality and allocate low weighting.

Table 2 shows the irrigation water quality standards and the unit weights assigned to each parameter used for calculating the $\mathrm{WQI}_{\mathrm{A}}$ index. Maximum weights were assigned to cadmium (0.7135), arsenic and chromium (0.07135) and to copper, manganese and nickel (0.03568), thus suggesting the key significance of these trace elements in water quality assessment and their considerable impact on the index.

Table 2. Standards for irrigation water and relative weight of parameters.

\begin{tabular}{|c|c|c|c|c|c|}
\hline No. & Parameter $^{1}$ & $\begin{array}{c}\text { Standards }^{2} \\
S i\end{array}$ & $1 / S i$ & K & Relative Weight $W i$ \\
\hline 1 & $\mathrm{pH}$ & $6.5-8.5$ & 0.1176 & \multirow{18}{*}{0.007} & 0.00084 \\
\hline 2 & Elect.Conduct.(EC) & 0.7 & 1.429 & & 0.01019 \\
\hline 3 & Sodium & 69 & 0.014 & & 0.00010 \\
\hline 4 & Chloride & 141.6 & 0.007 & & 0.00005 \\
\hline 5 & Boron & 0.7 & 1.429 & & 0.01019 \\
\hline 6 & Nitrate & 22.14 & 0.045 & & 0.00032 \\
\hline 7 & Bicarbonate & 91.46 & 0.011 & & 0.00008 \\
\hline 8 & Aluminum & 5.0 & 0.2 & & 0.00143 \\
\hline 9 & Arsenic & 0.10 & 10.0 & & 0.07135 \\
\hline 10 & Cadmium & 0.01 & 100 & & 0.71350 \\
\hline 11 & Chromium & 0.10 & 10.0 & & 0.07135 \\
\hline 12 & Copper & 0.20 & 5.0 & & 0.03568 \\
\hline 13 & Fluoride & 1.0 & 1.0 & & 0.00714 \\
\hline 14 & Iron & 5.0 & 0.2 & & 0.00143 \\
\hline 15 & Manganese & 0.20 & 5.0 & & 0.03568 \\
\hline 16 & Nickel & 0.20 & 5.0 & & 0.03568 \\
\hline 17 & Lead & 5.0 & 0.2 & & 0.00143 \\
\hline 18 & Zinc & 2.0 & 0.5 & & 0.00357 \\
\hline
\end{tabular}

${ }^{1}$ All values are in $\mathrm{mg} / \mathrm{L}$, except $\mathrm{pH}$ and $\mathrm{EC}\left(\mathrm{mS} \cdot \mathrm{cm}^{-1}\right) ;{ }^{2} \mathrm{FAO}$ [18]; source: own elaboration.

The CI was also calculated as a sum of the contamination factors of individual components (the 18 water quality parameters chosen for $\mathrm{WQI}_{\mathrm{A}}$ calculation, analyzed in the nine sampling campaigns), some of these exceeding the trigger values recommended by FAO [18]. The CI is determined by the following formula [26]:

$$
\mathrm{CI}=\sum_{\mathrm{i}=1}^{\mathrm{n}}\left[\left(\frac{\mathrm{C}_{\mathrm{Ai}}}{\mathrm{C}_{\mathrm{Ni}}}\right)-1\right]
$$

where $\mathrm{C}_{\mathrm{Ai}}$ and $\mathrm{C}_{\mathrm{Ni}}$ represent the analytical value and upper permissible concentration of the ith component, respectively. Note that $\mathrm{C}_{\mathrm{Ni}}$ is taken as maximum allowable concentration.

Based on the CI index, values less than 1,1-3, and more than 3 indicate low, medium and high levels of contamination, respectively [26].

TETI [28] was calculated based on the contaminants hazard intensity. The hazard intensity, or total score, of each parameter was determined according to the Toxicological Profiles of the Priority List of Hazardous Substances prepared by the Agency for Toxic Substances and Disease Registry (ATSDR), the Division of Toxicology and Environmental 
Medicine, Atlanta, GA, USA [46]. The ATSDR prioritization of substances is based on a combination of their frequency, toxicity, and potential for human exposure.

The concentration of each trace element detected was multiplied by its total score, and products were added to calculate TETI. The proposed TETI only considers toxic elements in water and is calculated by using the expression:

$$
\mathrm{TETI}=\sum_{\mathrm{i}=1}^{\mathrm{n}} \mathrm{C}_{\mathrm{i}} \times \mathrm{TS}_{\mathrm{i}}
$$

where $C_{i}$ is the concentration of each individual trace element and $\mathrm{TS}_{\mathrm{i}}$ is its Total Score (ATSDR). This index clearly represents the impact of mine activities on the aquatic environment, where the lower TETI value represents better water quality.

In addition to the conventional parameters of water quality, studies on organic pollutants as PAHs are also very important, as several mining activities such as coal mining, processing or storage of coal provide the basic conditions for the generation and release of these compounds.

As PAHs can also become a source of pollution after the abandonment of coal mines, the 16 priority hydrocarbons were analyzed in São Pedro da Cova samples in order to investigate contamination levels and distribution [47].

\subsection{Statistical Analysis}

Data obtained for different parameters were tested for distribution of the residuals with the Shapiro-Wilk's test. Chemical concentrations were studied using a one-way analysis of variance (ANOVA), if normal distribution of the residuals was confirmed. Welch correction was applied when the homogeneity of variances was not verified. Whenever statistical significances were found, Tukey's test or the Tamhane's test post-hoc tests were applied for mean comparison, depending on variances assumption or not. If normal distribution of the residuals was not found, the analyzed parameters were studied using a Kruskal-Wallis test. Whenever statistical significances were found, Dunn's post-hoc test was applied for median comparison. All statistical analyses were performed at $5 \%$ significance level using $R$ version 4.0.2 (R Project for Statistical Computing).

\section{Results and Discussion}

\subsection{Water chemistry}

The values of the physical and chemical parameters used to evaluate water quality from the two mine drainage galleries (G1 and G2, groundwater) and from Silveirinhos stream, collected upstream (SS-U) and downstream (SS-D) from the mine effluents discharge points are reported in Table 3. Results were compared to FAO guidelines in order to assess the water suitability for irrigation. The mining effluents G1 and G2 correspond to groundwater which circulates in the exploited rock massif as well as in the mine galleries. The SS-U water corresponds to surface water without mining influence and the SS-D water originates from the mixture of SS-U, G1 and G2 waters. 
Table 3. Summary statistics of physical and chemical parameters analyzed in mining effluents and in Silveirinhos stream. Comparison with FAO Guidelines for irrigation

\begin{tabular}{|c|c|c|c|c|c|c|c|c|c|}
\hline \multirow{3}{*}{$\begin{array}{c}\text { Parameters } \\
\text { Potential } \\
\text { Irrigation } \\
\text { Problem }\end{array}$} & \multicolumn{4}{|c|}{ FAO Guidelines for Irrigation [18] } & \multirow{3}{*}{$\begin{array}{l}\text { Silveirinhos } \\
\text { Stream } \\
\text { (SS-U) }\end{array}$} & \multirow{3}{*}{$\begin{array}{c}\text { Mine } \\
\text { Wastewater } \\
\text { (G1) }\end{array}$} & \multirow{3}{*}{$\begin{array}{c}\text { Mine } \\
\text { Wastewater } \\
\text { (G2) }\end{array}$} & \multirow{3}{*}{$\begin{array}{l}\text { Silveirinhos } \\
\text { Stream } \\
\text { (SS-D) }\end{array}$} & \multirow{3}{*}{$p$} \\
\hline & \multirow[b]{2}{*}{ Units } & \multicolumn{3}{|c|}{ Degree of Restriction on Use } & & & & & \\
\hline & & None & $\begin{array}{l}\text { Slight to } \\
\text { Moderate }\end{array}$ & Severe & & & & & \\
\hline \multicolumn{10}{|c|}{ Salinity (affects crop water availability) } \\
\hline EC & $\mathrm{dS} / \mathrm{m}$ & $<0.7$ & $0.7-3.0$ & $>3.0$ & $0.08 \pm 0.02 c$ & $0.84 \pm 0.14 \mathrm{a}$ & $0.92 \pm 0.18 \mathrm{a}$ & $0.56 \pm 0.21 \mathrm{~b}$ & $<0.0001 \# \#$ \\
\hline \multicolumn{10}{|c|}{ Specific Ion toxicity (affects sensitive crops) } \\
\hline Sodium (Na) & $\mathrm{meq} / \mathrm{L}$ & $<3$ & $3-9$ & $>9$ & $0.32 \pm 0.04 \mathrm{~b}$ & $1.03 \pm 0.08 \mathrm{a}$ & $1.03 \pm 0.06 \mathrm{a}$ & $0.78 \pm 0.22 \mathrm{a}$ & $<0.0001$ \#\# \\
\hline Boron (B) & $\mathrm{mg} / \mathrm{L}$ & $<0.7$ & $0.7-3.0$ & $>3.0$ & $0.07 \pm 0.02 \mathrm{a}$ & $0.24 \pm 0.07 \mathrm{bc}$ & $0.26 \pm 0.08 \mathrm{c}$ & $0.14 \pm 0.05 \mathrm{ab}$ & $0.00127 \#$ \\
\hline \multicolumn{10}{|c|}{ Trace Elements $\left({ }^{*}\right.$ Recommended Maximum Concentration) } \\
\hline Aluminum (Al) & $\mathrm{mg} / \mathrm{L}$ & & $5.0^{*}$ & & $0.19 \pm 0.05 \mathrm{a}$ & $0.37 \pm 0.06 \mathrm{~b}$ & $0.44 \pm 0.09 \mathrm{c}$ & $0.21 \pm 0.19 \mathrm{ab}$ & $0.0359 \#$ \\
\hline Arsenic (As) & $\mathrm{mg} / \mathrm{L}$ & & $0.10^{*}$ & & $0.001 \pm 0.001 \mathrm{~d}$ & $0.015 \pm 0.005 \mathrm{a}$ & $0.034 \pm 0.009 \mathrm{~b}$ & $0.008 \pm 0.003 c$ & $<0.0001 \# \#$ \\
\hline Cadmium $(\mathrm{Cd})$ & $\mathrm{mg} / \mathrm{L}$ & & $0.01^{*}$ & & $<\mathrm{LD}$ & $<\mathrm{LD}$ & $<\mathrm{LD}$ & $<\mathrm{LD}$ & - \\
\hline Chromium (Cr) & $\mathrm{mg} / \mathrm{L}$ & & $0.10^{*}$ & & $<\mathrm{LD}$ & $<\mathrm{LD}$ & $<\mathrm{LD}$ & $<\mathrm{LD}$ & - \\
\hline Copper $\mathrm{Cu}$ ) & $\mathrm{mg} / \mathrm{L}$ & & 0.20 * & & $<\mathrm{LD}$ & $<\mathrm{LD}$ & $<\mathrm{LD}$ & $<\mathrm{LD}$ & - \\
\hline Fluoride $(\mathrm{F})$ & $\mathrm{mg} / \mathrm{L}$ & & $1.0^{*}$ & & $0.04(0.00-0.07) \mathrm{b}$ & $0.29(0.00-0.38) \mathrm{a}$ & $0.33(0.16-0.35) \mathrm{a}$ & $0.15(0.09-0.27) \mathrm{ab}$ & $0.0001 \&$ \\
\hline Iron $(\mathrm{Fe})$ & $\mathrm{mg} / \mathrm{L}$ & & $5.0 *$ & & $0.12(0.03-0.47) \mathrm{c}$ & $\begin{array}{c}52.28(45.66-62.39) \\
a b\end{array}$ & $\begin{array}{c}84.66(57.65- \\
115.08) \\
a\end{array}$ & $\begin{array}{c}18.24(15.72-62.79) \\
\mathrm{b}\end{array}$ & $<0.0001 \&$ \\
\hline $\begin{array}{l}\text { Manganese } \\
(\mathrm{Mn})\end{array}$ & $\mathrm{mg} / \mathrm{L}$ & & 0.20 * & & $0.06 \pm 0.02 b$ & $4.96 \pm 1.08 \mathrm{a}$ & $4.82 \pm 1.16 \mathrm{a}$ & $2.93 \pm 1.72 \mathrm{a}$ & $<0.0001$ \#\# \\
\hline Nickel (Ni) & $\mathrm{mg} / \mathrm{L}$ & & 0.20 * & & $<\mathrm{LD} \mathrm{b}$ & $0.04(0.00-0.05) \mathrm{a}$ & $0.02(0.00-0.03) \mathrm{ab}$ & $0.02(0.00-0.03) \mathrm{ab}$ & $0.0008 \&$ \\
\hline Lead $(\mathrm{Pb})$ & $\mathrm{mg} / \mathrm{L}$ & & $5.0 *$ & & $<\mathrm{LD}$ & $<\mathrm{LD}$ & $<\mathrm{LD}$ & $<\mathrm{LD}$ & - \\
\hline Zinc $(\mathrm{Zn})$ & $\mathrm{mg} / \mathrm{L}$ & & $2.0^{*}$ & & $0.01(0.00-0.90)$ & $0.00(0.00-0.08)$ & $0.00(0.00-0.03)$ & $0.00(0.00-0.03)$ & n.s. \\
\hline \multicolumn{10}{|c|}{ Miscellaneous Effects (affects susceptible crops) } \\
\hline $\begin{array}{c}\text { Nitrate }\left(\mathrm{NO}_{3}-\mathrm{N}\right) \\
1\end{array}$ & $\mathrm{mg} / \mathrm{L}$ & $<5$ & $5-30$ & $>30$ & $0.42(0.23-2.20)$ & $0.28(0.00-1.62)$ & $0.28(0.00-0.67)$ & $0.61(0.05-0.91)$ & n.s. \\
\hline $\begin{array}{c}\text { Bicarbonates } \\
\left(\mathrm{HCO}_{3}\right)\end{array}$ & meq/L & $<1.5$ & $1.5-8.5$ & $>8.5$ & $0.12 \pm 0.03 c$ & $2.99 \pm 0.70 \mathrm{ab}$ & $3.37 \pm 1.04 \mathrm{a}$ & $1.71 \pm 1.10 \mathrm{~b}$ & $<0.0001$ \#\# \\
\hline $\begin{array}{c}\text { Carbonates } \\
\left(\mathrm{CO}_{3}\right)\end{array}$ & meq/L & & & & $<\mathrm{LD}$ & $<\mathrm{LD}$ & $<\mathrm{LD}$ & $<\mathrm{LD}$ & - \\
\hline $\mathrm{pH}$ & & & nal range 6 & & $\begin{array}{c}\text { 6.26(6.17-6.56) } \\
a b\end{array}$ & $6.16(6.09-6.44) \mathrm{a}$ & $6.12(6.00-6.57)$ a & $6.51(6.23-6.70) b$ & $0.0005 \&$ \\
\hline Turbidity & NTU & & & & $1.1(0.3-4.9) \mathrm{b}$ & $74.2(9.0-328.5) \mathrm{a}$ & $111.5(1.9-342.0) \mathrm{a}$ & $32.5(5.3-109.6) \mathrm{ab}$ & $0.0008 \&$ \\
\hline Cyanide & $\mathrm{mg} / \mathrm{L}$ & & & & $<\mathrm{LD}$ & $<\mathrm{LD}$ & $<\mathrm{LD}$ & $<\mathrm{LD}$ & - \\
\hline
\end{tabular}


Table 3. Cont

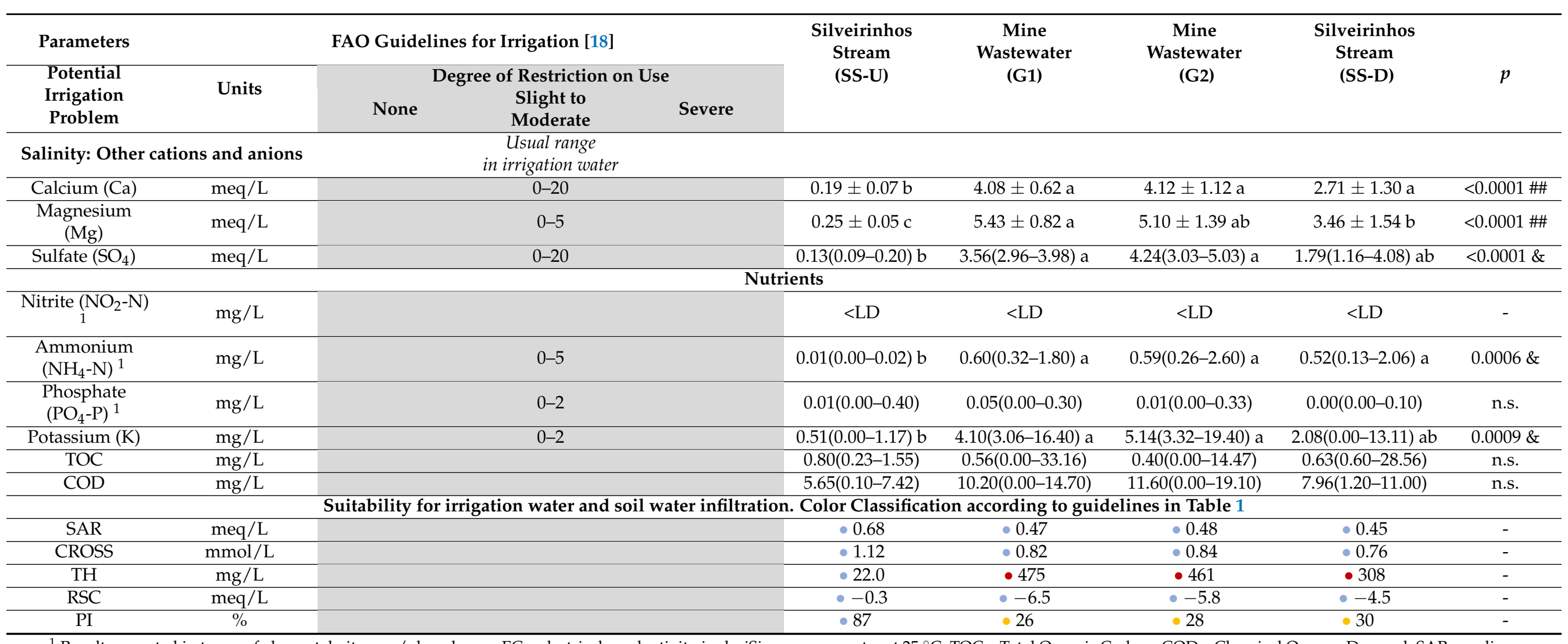

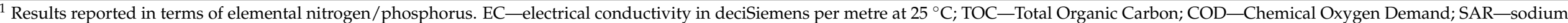

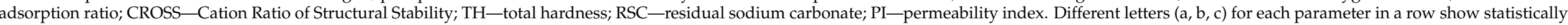

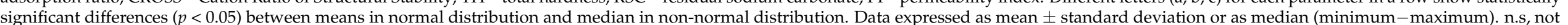

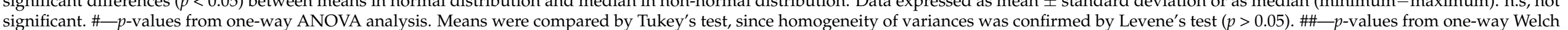

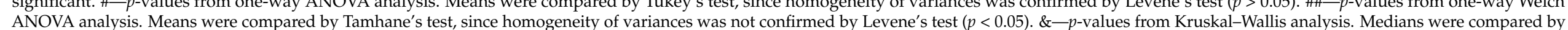

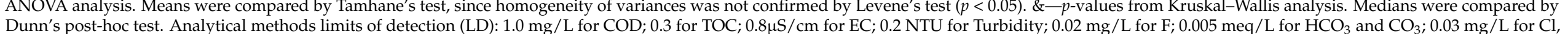

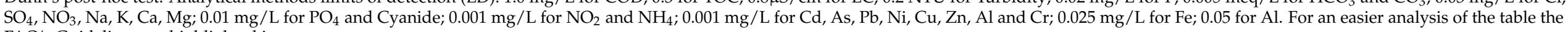
FAO's Guidelines are highlighted in gray. 
The water samples from Silveirinhos stream collected upstream from the galleries (SS-U) showed results within FAO's permissible limits for irrigation purposes, with the exception of $\mathrm{pH}$ values, which were slightly below 6.5 due to the geological features of the catchment. Water samples from the mine drainage galleries G1 and G2 reflect the geochemical system of the coal seams and overlying strata. These mining effluents are not as acidic as one might expect, being neutral to slightly acidic, with $\mathrm{pH}$ values close to FAO's inferior permissible limit.

Acidity in coal mine waters results mainly from the dissolution of oxidized pyritic materials associated with coal, during mining operations, which explains the existence of iron and sulphate in the water. The $\mathrm{pH}$ values of samples G1 and G2, concomitantly with their high levels of iron and sulphate, suggest the existence of an underground neutralization process. The scarcity of pyrites in particular layers and the predominance of carbonate minerals constitute the most common explanation for neutral or alkaline mine drainages [48]. However, the calcareous materials in this region are very scarce and do not constitute a reasonable justification. In São Pedro da Cova, a plausible origin of the neutralization process could be the mixture of acid groundwater, circulating in the shallow rock massif along the mine galleries and wells, with alkaline thermomineral water following deeper circulation paths, possibly through major faults. This hypothesis is corroborated by the relatively high fluoride content in G1 and G2 samples (a hydrogeochemical signature of thermomineral circulation), when compared to SS-U samples, and by the water temperature measured in situ during the nine sampling campaigns. Data analysis shows that the temperatures measured in mine effluents were higher than the average annual air temperature for the study area $\left(15^{\circ} \mathrm{C}\right)$, ranging from $9{ }^{\circ} \mathrm{C}$ in January to $20^{\circ} \mathrm{C}$ in July. G1 and G2 temperatures remained constant during the study, with mean values of $18.9 \pm 0.5$ and $19.1 \pm 0.4{ }^{\circ} \mathrm{C}$, respectively, which are significantly higher than the mean water temperature in SS-U $\left(15.4 \pm 4.7^{\circ} \mathrm{C}\right)$. SS-U water temperature is seasonal, and it closely follows changes in air temperature as can be seen in Figure 3. In SS-D the influence of the mining drainages is notorious, with a mean value of temperature of $17.3 \pm 1.8^{\circ} \mathrm{C}$.

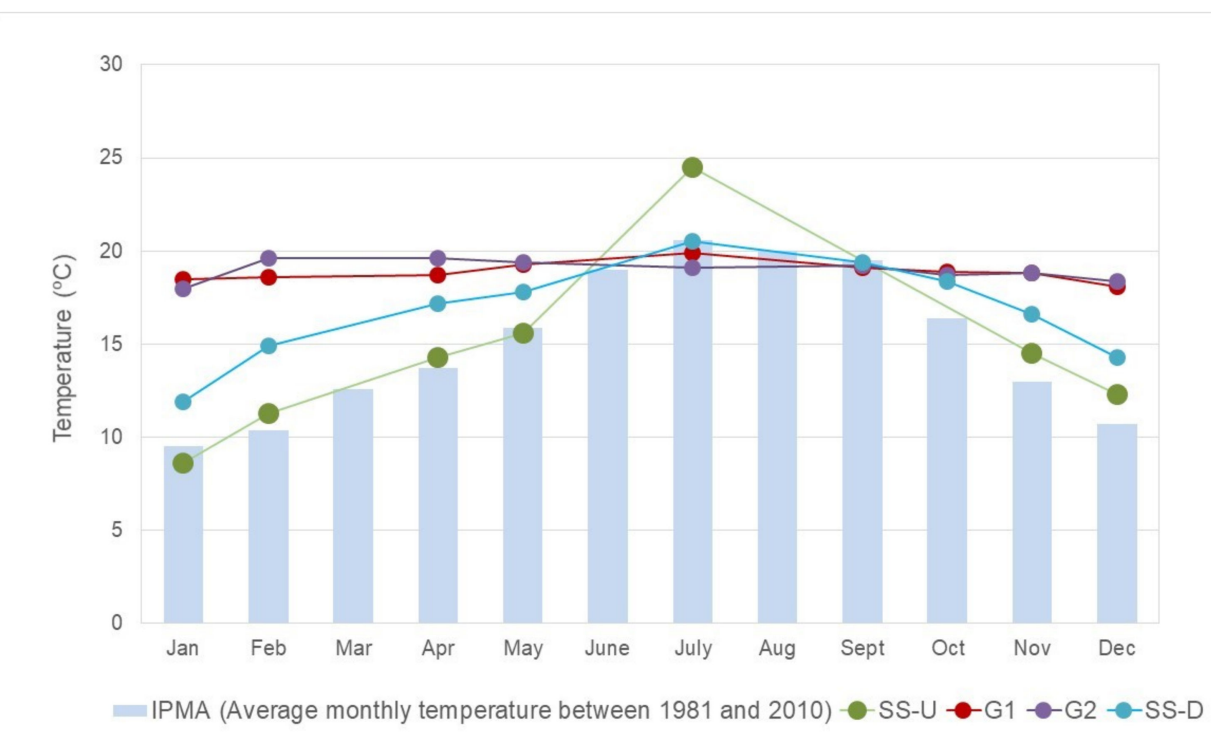

Figure 3. Average monthly air temperature measured between 1981 and 2010 in Serra do Pilar weather station (IPMA). Water temperature recorded at the sampling points SS-U, G1, G2 and SS-D on April, June, October and December 2017, January and November 2018, and February, May, September and December 2019.

The number of particles in water can be expressed by turbidity. With the exception of the SS-U samples that recorded a turbidity median value of 1.1 NTU (Table 3), all the impacted waters have values that were far above the limits proposed by the US EPA of 
2 NTU for directly consumed crops and unrestricted irrigation [49], and by Spain that recommends levels lower than 10 NTU for vegetable irrigation water [15].

High levels of turbidity can affect the performance of irrigation facilities, causing the clogging of the equipment, can lower the hydraulic conductivity of the soil, pollute the soil surface, and lead to aesthetic impairment of the water and of the vegetables produced. In addition, irrigating vegetables with turbid water could affect the quality of the products since microorganisms, such as parasites, bacteria and viruses can be attached to the solid particles and contaminate the crops [18].

The EC is also a significant parameter in determining the suitability of water for irrigation use, as it affects water salinity, which subsequently affects the productivity and yield of crops. The EC levels obtained in this study were all below the $3.0 \mathrm{dS} / \mathrm{m}$ permissible limit set by FAO for irrigation water [18]. However, the levels recorded in G1 and G2 were significantly higher than those recorded in Silveirinhos stream upstream from mine drainage galleries, these waters having a slight to moderate restriction on use.

Regarding major ions, the levels in SS-U were within FAO permissible limits, and significantly lower than in the impacted waters. Coal mining pollution significantly increases mineralization as a result of a greater water-rock interaction. $\mathrm{Mg}^{2+}$ and $\mathrm{K}^{+}$were above the usual range for irrigation water, being the abundance of the ions as follows: $\mathrm{SO}_{4}{ }^{2-}>\mathrm{Mg}^{2+}>\mathrm{Ca}^{2+}>\mathrm{HCO}_{3}{ }^{-}>\mathrm{Na}^{+}>\mathrm{Cl}^{-}>\mathrm{K}^{+}>\mathrm{CO}_{3}{ }^{2-}$.

The hydrogeochemical effect of coal mining, in terms of hydrogeochemical facies and major ion content, is illustrated by means of a Piper diagram (Figure 4) and a Stiff diagram (Figure 5). Surface water without mining influence (SS-U) has an intermediate $\mathrm{SO}_{4} / \mathrm{Cl}-\mathrm{Na} / \mathrm{Mg}$ classification while mine drainage waters (G1 and G2) as well as the water collected downstream from the mining effluents discharge (SS-D) have a hydrogeochemical $\mathrm{SO}_{4}-\mathrm{Mg}$ facies.

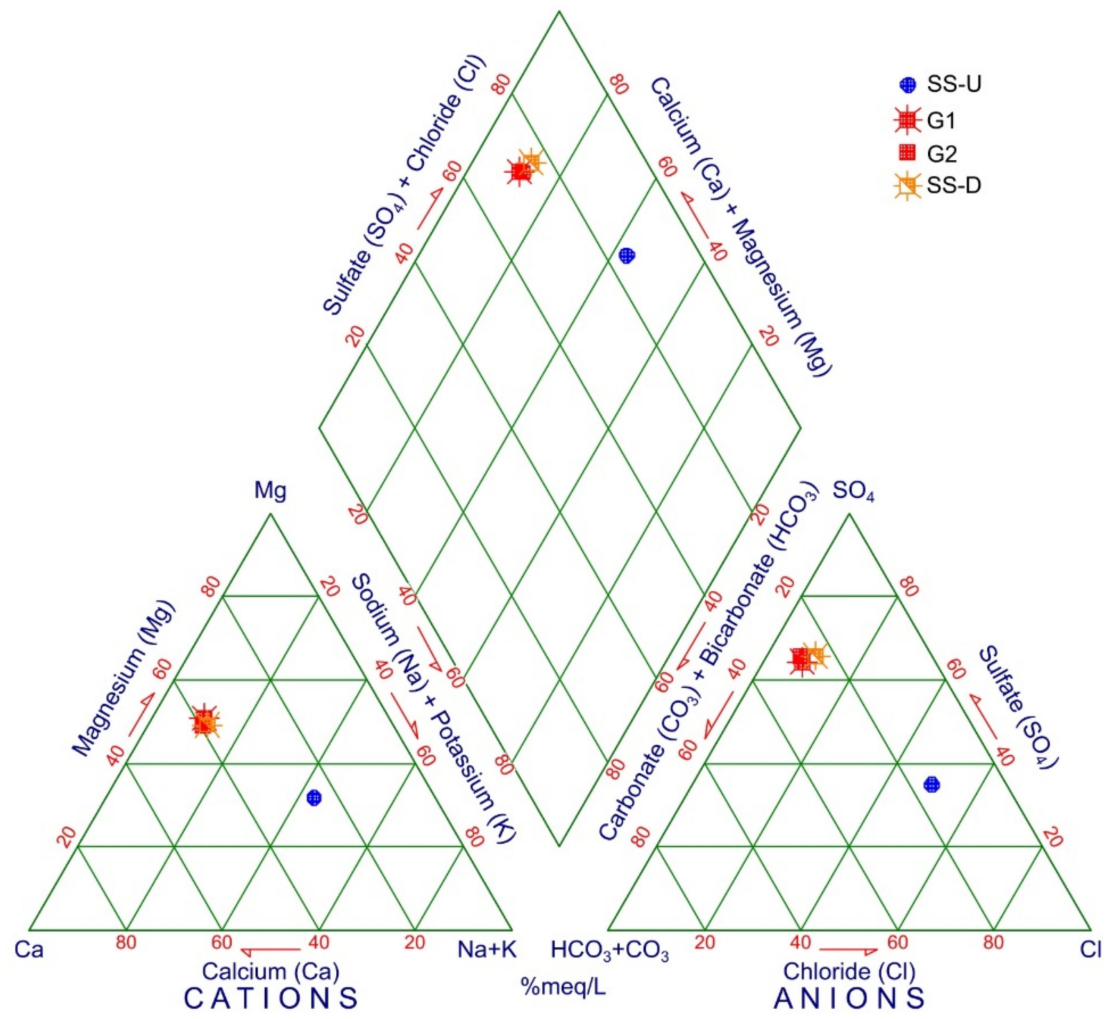

Figure 4. Piper diagram of the studied waters (average values from April 2017 to December 2019, $n=9$ ). 


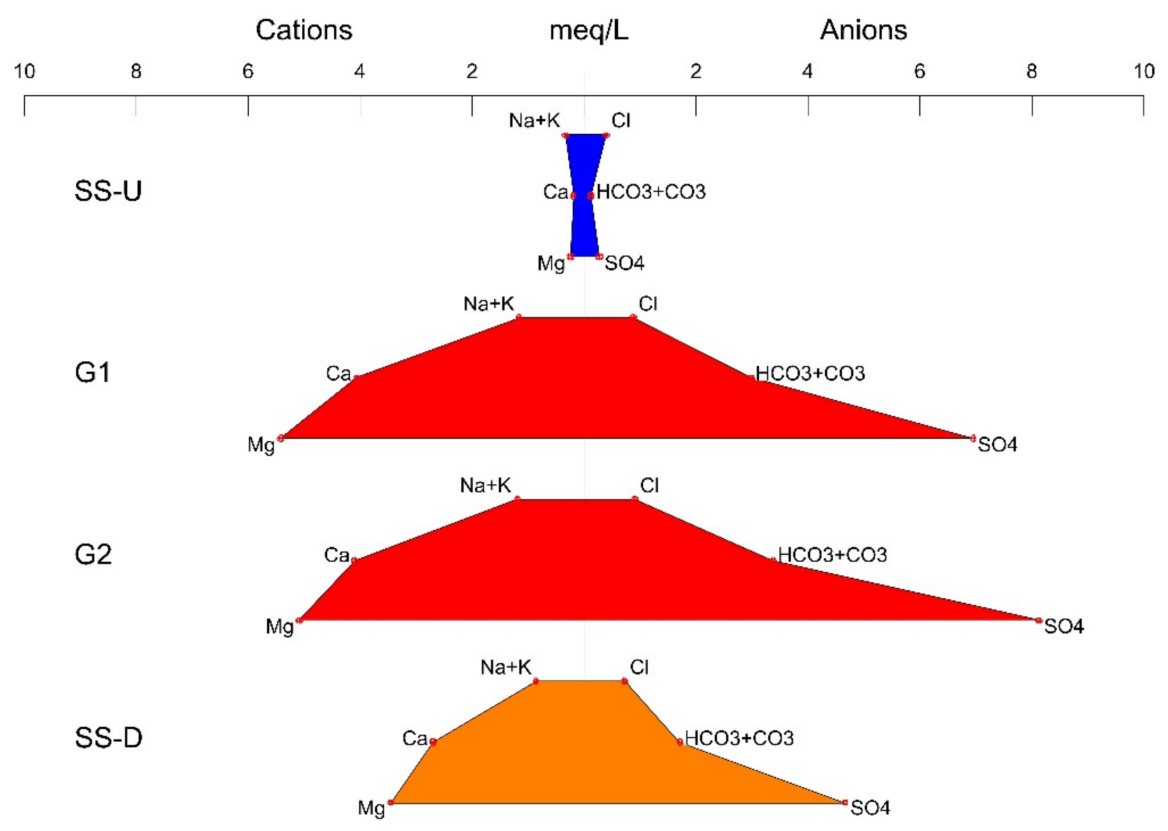

Figure 5. Stiff diagram of the studied waters (average values from April 2017 to December 2019, $n=9$ ).

Sulfate is relatively common in water and has no major impact on soil other than contributing to the total salt content. Despite being within the usual range for irrigation (0-20 meq/L), concentrations of sulfate in G1 and G2 mine effluents, and in SS-D, were 26 and 17 times higher, respectively, than in SS-U, highlighting the mining influence. Chloride also contributes to the salinity of soils. It is necessary for plant growth in small amounts, but in high concentrations can inhibit plant growth or be toxic to some plants. In the studied waters, chloride levels were low, although G1 and G2 recorded two times the concentration of the upstream water samples.

Regarding the bicarbonate levels, G1 and G2 samples exhibited more than 25 times, and the SS-D samples more than 14 times, the concentration found in the SS-U samples, confirming the mining impact. High levels of bicarbonates can be directly toxic to some plant species. Levels greater than $1.5 \mathrm{meq} / \mathrm{L}$ are sufficient to cause concern. Concentrations of bicarbonates greater than $3.3 \mathrm{meq} / \mathrm{L}$ may pose a severe potential hazard. Bicarbonate reacts with calcium forming deposits of calcium carbonate and render calcium unavailable. Bicarbonate is also toxic to roots and reduces shoot growth, the uptake of phosphorus and of several micronutrients $[13,15,18]$.

Calcium and magnesium are essential plant nutrients that occur naturally in water through the weathering of geological materials that contain these elements. However, in high concentrations, they are associated to soil aggregation and friability, being important qualitative criteria in the assessment of irrigation water quality. The average concentrations of magnesium in G1 and G2 mine waters ( 5.43 and $5.10 \mathrm{meq} / \mathrm{L}$, respectively) were above FAO guidelines ( $0-5 \mathrm{meq} / \mathrm{L})$. Calcium concentrations varied from 0.19 in SS-U to $4.12 \mathrm{meq} / \mathrm{L}$ in $\mathrm{G} 2$, far below the limit of $20 \mathrm{meq} / \mathrm{L}$ of FAO.

These results correlate with the $\mathrm{TH}$ values that were also calculated to categorize the water samples considering their calcium and magnesium contents, using the formula shown in Table 1. TH calculated mean values for G1, G2 and SS-D samples were 476, 461 and $308 \mathrm{mg} / \mathrm{L}$, respectively, indicating very hard waters that can be considered harmful and unsuitable for irrigation use. In contrast, the SS-U samples are classified as soft, with a mean value of TH of $22 \mathrm{mg} / \mathrm{L}$.

The RSC index was also calculated as it is an important parameter for irrigation used to indicate the alkalinity hazard for soil. RSC compares the relative concentrations of bicarbonate and carbonate ions with the concentrations of calcium and magnesium. The 
average RSC values were negative for all samples ( $<1.25 \mathrm{meq} / \mathrm{L})$, indicating that according to this index waters are safe for irrigation.

Sodium and potassium also occur naturally in groundwater and surface water due to normal water-rock interaction. Among the soluble constituents of irrigation water, sodium is considered the most hazardous. High concentrations of sodium are undesirable because it adsorbs on to the soil cation exchange particles, causing deflocculation and pore sealing, decreasing soil permeability. In the studied water samples, sodium concentrations were low, with mean values varying from 0.32 in SS-U to $1.03 \mathrm{meq} / \mathrm{L}$ in G1 and G2. Otherwise, the mean concentrations of potassium in G1 and G2 were 5.2 and $6.7 \mathrm{mg} / \mathrm{L}$, respectively, about three times higher than FAO's limit of $2 \mathrm{mg} / \mathrm{L}$ [18]. In SS-D the mean concentration was $3.1 \mathrm{mg} / \mathrm{L}$, also above the recommended limit.

Decades of research on the effect of irrigation water quality on soil permeability have established that the decreasing order of negative impacts of the four major cations follows the sequence: $\mathrm{Na}>\mathrm{K}>\mathrm{Mg}>\mathrm{Ca}$, although the current guidelines are still based on SAR and assume that potassium and magnesium pose no hazard. However, recent studies demonstrated that the negative effects of high $\mathrm{K}$ and $\mathrm{Mg}$ concentrations on soil permeability are substantial and that they should be taken into account through a new irrigation water quality parameter, the Cation Ratio of Structural Stability (CROSS) that can be directly incorporated into existing irrigation water quality guidelines by replacing SAR [50]. CROSS quantifies both the differing effects of $\mathrm{Na}$ and $\mathrm{K}$ as dispersing cations diminishing soil permeability and the differing effects of $\mathrm{Mg}$ and $\mathrm{Ca}$ as flocculating cations enhancing soil permeability. The interpretative guidelines for irrigation water quality involving SAR and CROSS are similar [51].

As mine waters are non-conventional irrigation waters and results revealed high levels of $\mathrm{K}$ and $\mathrm{Mg}$, the CROSS ratio was also calculated by the following formula:

$$
\text { CROSS }=\frac{\mathrm{Na}^{+}+0.56 \mathrm{~K}^{+}}{\sqrt{\left(\mathrm{Ca}^{2+}+0.6 \mathrm{Mg}^{2+}\right) / 2}}
$$

where the concentrations of ions $(\mathrm{Na}, \mathrm{K}, \mathrm{Ca}$, and $\mathrm{Mg}$ ) are expressed in mmol/L. CROSS results were similar to SAR values, varying from 1.1 in SS-D to 0.8 in G1, G2 and SS-U. According to Richards (1954) [40] and FAO guidelines [18], all samples fall in the excellent section for irrigation, which is in accordance with RSC values. Concerning the permeability index (PI) results, only the SS-U samples were classified as of good quality, with more than $75 \%$ of maximum permeability. The impacted waters, although classified in Class II, presented values close to $25 \%$, which can be considered unsuitable for irrigation (Table 3).

Thus, considering the characteristics discussed above, it can be concluded that the SS-U water is excellent for irrigation, but the mutual balancing of cations and anions leads to contradictory classifications of the aptness of G1, G2 and SS-D water samples for irrigation purposes. According to SAR, CROSS, and RSC values waters can be classified as good/excellent for irrigation, whilst according to TH and PI they are considered unsuitable.

Plant nutrient concentrations (nitrate, nitrite, ammonium and phosphate) and organic matter content (TOC and COD) were low in all water samples during the entire study period. Nitrate and phosphate are essential plant nutrients, but when in excessive amounts can cause water quality problems and accelerate eutrophication, altering the density and types of aquatic plants found in affected water bodies, promoting their degradation.

Boron is essential for the normal plant growth, but its occurrence in toxic concentrations makes it necessary to consider this element in assessing the water quality. Boron mean values in water samples ranged from $0.07 \mathrm{mg} / \mathrm{L}$ in SS-U to $0.26 \mathrm{mg} / \mathrm{L}$ in G2. Values are within acceptable threshold, not included in the restriction categories of the FAO classification.

Finally, several trace elements, mainly metals, were also analyzed as they are necessary for crop growth but when in high doses can cause serious environmental and health hazards. Their quantitative determination has shown that the waters affected by coal 
mining activities have higher metal content, especially iron, manganese, aluminum, nickel and arsenic, which may cause various health hazards such as cancer and environmental pollution. Only iron and manganese exceeded the FAO standards, with values far above the recommended concentrations, but the levels of aluminum almost duplicated in the impacted waters, and nickel and arsenic increased significantly in G1, G2 and SS-D, in a proportion of 7, 3, 3 times and 21, 48, 11 times, respectively, in comparison with the values in water samples collected upstream from the discharges.

Iron was the most abundant metal detected in the mine wastewater samples and in the samples collected downstream from the mine galleries. The median concentration of iron ranged from $0.12 \mathrm{mg} / \mathrm{L}$ in SS-U to 52.28 and $84.66 \mathrm{mg} / \mathrm{L}$ in G1 and G2, respectively, and $18.24 \mathrm{mg} / \mathrm{L}$ in SS-D. Iron can be a complex water quality problem, which not only affects plant growth, as it can compete with other needed micro-nutrients, but also can clog irrigation equipment. For micro-irrigation systems, iron levels need to be below $0.3 \mathrm{mg} / \mathrm{L}$ to prevent clogging. Above $1.0 \mathrm{mg} / \mathrm{L}$, iron may lead to rust stains and discoloration on foliage plants in overhead irrigation systems, and above $5 \mathrm{mg} / \mathrm{L}$ iron is toxic to plant tissues.

Manganese presents many of the same issues as iron in irrigation water. It can clog irrigation equipment and cause foliar staining. The recommended drinking water standard for manganese is $0.05 \mathrm{mg} / \mathrm{L}$, which is also the level where black staining and irrigation clogging may occur. Concentrations above $2.0 \mathrm{mg} / \mathrm{L}$ can be directly toxic to some plant species. In this study the mean concentration of manganese ranged from $0.06 \mathrm{mg} / \mathrm{L}$ in SS-U to $4.96 \mathrm{mg} / \mathrm{L}$ in G1.

\subsection{Irrigation Water Quality Indices}

As the results suggest that no unique parameter can sufficiently describe water quality, thus, the chemical status of the water samples was also assessed by using Water Pollution Indices. Indices were calculated covering a wide range of variables that were gathered in a single numerical value, allowing a simplified representation of a complex reality and also the evaluation of historical trends. The most significant parameters for the water quality evaluation were selected according to FAO's guidelines, and for TETI according to the Toxicological Profiles of the Priority List of Hazardous Substances of ATSDR, in order to proceed with the calculation of the indices in a robust but simple way, using the smallest number of analytes. Indices calculations were also performed including other parameters, but no differences were found in the results and in the outcomes of the evaluation.

The results of the WQIA and the CI indices are shown in Table 4. From WQIA values waters were classified into five categories: excellent, good, poor, very poor and unsuitable, and CI values indicate a low, medium or high level of contamination.

Table 4. Calculated values of $\mathrm{WQI}_{\mathrm{A}}$ (Water Quality Status) and CI (Level of Contamination).

\begin{tabular}{|c|c|c|c|c|c|c|c|c|}
\hline \multirow{2}{*}{$\begin{array}{l}\text { Sampling } \\
\text { Date }\end{array}$} & \multicolumn{4}{|c|}{$\mathrm{WQI}_{\mathrm{A}}$} & \multicolumn{4}{|c|}{ CI ${ }_{\text {Degree of Contamination }}$} \\
\hline & SS-U & G1 & G2 & SS-D & SS-U & G1 & G2 & SS-D \\
\hline apr17 & 2.8 & 99.3 & 85.3 & 47.3 & -13.3 & 32.5 & - 32.4 & 6.4 \\
\hline jun17 & - 3.2 & - 110.8 & - 107.3 & -94.0 & -12.5 & - 34.5 & - 40.0 & - 24.0 \\
\hline sep17 & - & - 129.8 & - 140.1 & - 105.4 & - & - 41.2 & - 55.3 & - 30.1 \\
\hline $\operatorname{dec} 17$ & - 2.0 & - 100.3 & - 101.1 & - 47.5 & -13.2 & 28.9 & - 40.8 & - 3.9 \\
\hline nov18 & $\bullet 1.7$ & 96.1 & - 101.0 & - 40.9 & -15.5 & - 30.3 & - 35.5 & - 10.3 \\
\hline feb19 & - 1.4 & 75.4 & 73.2 & - 32.5 & -15.3 & - 18.5 & - 27.0 & -1.2 \\
\hline may19 & • 1.7 & • 81.0 & • 81.8 & 35.6 & -15.8 & - 26.0 & - 30.4 & -1.7 \\
\hline sep19 & - & • 87.9 & - 86.3 & 86.1 & - & - 31.6 & - 38.8 & 26.5 \\
\hline dec19 & • 1.5 & 66.2 & 69.4 & • 16.2 & -16.2 & • 20.7 & - 22.0 & -7.0 \\
\hline Avg & - 2.0 & 94.1 & - 93.9 & 56.2 & -14.5 & - 29.4 & - 35.8 & - 10.1 \\
\hline
\end{tabular}

Water Quality Status (WQI $)$ : Excellent (0-25•); Good (26-50॰); Poor (51-75 ); Very Poor $(76-100 \bullet)$; Unsuitable (>100 •). Level of contamination $(\mathrm{CI})$ : Low $(<1 \bullet)$; medium $(1-3 \bullet)$; high $(>3 \bullet)$. 
The relation of precipitation events with the $\mathrm{WQI}_{\mathrm{A}}$ values is represented in Figure 6, with data highlighted in different colors according to the classification for irrigation purposes (Legend Table 4).

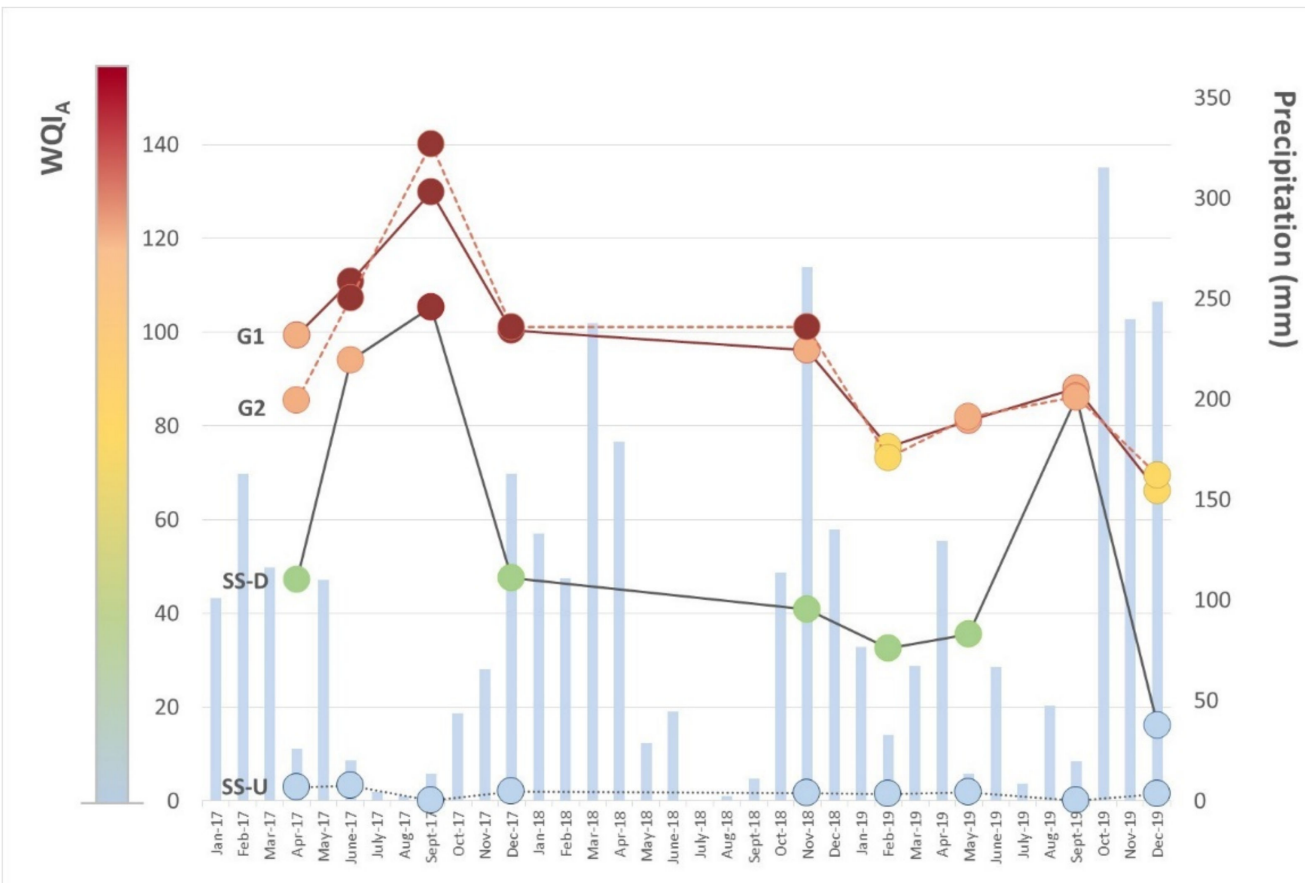

Figure 6. Relation between precipitation and water quality assessed by means of $\mathrm{WQI}_{\mathrm{A}}$. Precipitation measured at Porto meteorological station. Data from the Portuguese Institute for Sea and Atmosphere, I. P. (IPMA, IP) [52].

Results comparing upstream and downstream sampling sites point out the impact of mining effluents on surface water, being SS-U classified as excellent $\left(\mathrm{WQI}_{\mathrm{A}}\right.$ values ranging from 1.4 to 3.2, with a mean value of 2.0) and SS-D as poor (WQIA values ranging from 16.2 to 105.4 , with a mean value of 56.2). Analysis also revealed that G1 and G2 were, as expected, the two most polluted waters, reported as very poor, with values ranging from 66.2-129.8 and 69.4-140.1, respectively. Out of the 18 parameters considered for this study, iron and manganese were the two deciding parameters, followed by arsenic and EC, which exhibit the maximum influence (Qi $x \mathrm{Wi}$ ) in the $\mathrm{WQI}_{\mathrm{A}}$ calculations.

Figure 6 shows fluctuations in $\mathrm{WQI}_{\mathrm{A}}$ values in both study periods: from April 2017 to December 2017 and from November 2018 to December 2019. In the first period, the effect of draught in water quality is clear: the highest $\mathrm{WQI}_{\mathrm{A}}$ values correspond to the driest months due to the lack of mixture of mine drainage with recently infiltrated precipitation. In the second period, a similar trend is observed in September 2019, with G1, G2 and SS-D presenting similar values. It was not possible to collect samples on SS-U because there was no streamflow due the drought conditions. The lower $\mathrm{WQI}_{\mathrm{A}}$ values from this period were observed in February and in December 2019 as a result of a dilution effect due the infiltration of precipitation in the previous months.

The results of the computed CI index are, in general, comparable with the $\mathrm{WQI}_{\mathrm{A}}$ values. The CI results for impacted waters exceeded the value of 3 , ranging from a mean value of 10.1 in SS-D to 29.4 in G1 and 35.8 in G2, which indicates a high degree of pollution due mainly to iron, manganese and bicarbonate content, which exceed the limits of FAO guidelines. The SS-U samples have their computed CI values below 1, reflecting the absence of coal mining influence.

TETI results, based on the elemental toxicological impact, are shown in Table 5. 
Table 5. Trace element toxicity index values.

\begin{tabular}{|c|c|c|c|c|c|c|c|c|c|}
\hline & \multirow{2}{*}{ Tsi } & \multicolumn{2}{|c|}{$S S-U$} & \multicolumn{2}{|c|}{ G1 } & \multicolumn{2}{|c|}{ G2 } & \multicolumn{2}{|c|}{$S S-D$} \\
\hline & & $\mathbf{C i}$ & $\mathrm{Ci} \times \mathrm{Tsi}$ & $\mathbf{C i}$ & $\mathrm{Ci} \times \mathrm{Tsi}$ & $\mathrm{Ci}$ & $\mathrm{Ci} \times \mathrm{Tsi}$ & $\mathrm{Ci}$ & $\mathrm{Ci} \times \mathrm{Tsi}$ \\
\hline$K$ (Potassium) $m g / L$ & 607 & 0.61 & 371.14 & 5.16 & 3134.48 & 6.74 & 4089.83 & 3.08 & 1867.54 \\
\hline $\mathrm{NO}_{3}$ (Nitrate) mg/L & 605 & 0.71 & 428.69 & 0.46 & 276.96 & 0.26 & 154.61 & 0.56 & 336.11 \\
\hline $\mathrm{NO}_{2}$ (Nitrite) $\mathrm{mg} / \mathrm{L}$ & 610 & 0.003 & 2.09 & 0.01 & 5.69 & 0.01 & 7.59 & 0.02 & 9.83 \\
\hline $\mathrm{NH}_{4}($ Ammonia $) \mathrm{mg} / \mathrm{L}$ & 742 & 0.01 & 3.92 & 0.76 & 560.37 & 0.84 & 625.88 & 0.73 & 543.56 \\
\hline $\mathrm{PO}_{4}$ (Phosphate) $\mathrm{mg} / \mathrm{L}$ & 264 & 0.15 & 40.43 & 0.15 & 38.34 & 0.27 & 72.19 & 0.12 & 32.65 \\
\hline CN (Cyanide) $\mathrm{mg} / \mathrm{L}$ & 1070 & 0.001 & 0.79 & 0.00 & 1.12 & 0.00 & 1.08 & 0.00 & 1.11 \\
\hline$B$ (Boron) $m g / L$ & 440 & 0.07 & 30.25 & 0.24 & 103.49 & 0.26 & 112.55 & 0.14 & 61.95 \\
\hline$A l$ (Aluminum) $m g / L$ & 685 & 0.19 & 129.07 & 0.37 & 250.39 & 0.44 & 300.78 & 0.21 & 142.85 \\
\hline As (Arsenic) $m g / L$ & 1676 & 0.001 & 1.20 & 0.02 & 25.26 & 0.03 & 57.51 & 0.01 & 13.65 \\
\hline$C d($ Cadmium $) m g / L$ & 1318 & 0.000 & 0.14 & 0.00 & 0.03 & 0.00 & 0.01 & 0.00 & 0.07 \\
\hline $\mathrm{Cr}$ (Chromium) $\mathrm{mg} / \mathrm{L}$ & 893 & 0.001 & 1.05 & 0.00 & 0.72 & 0.00 & 0.57 & 0.00 & 0.45 \\
\hline$C u$ (Copper) $m g / L$ & 805 & 0.003 & 2.19 & 0.00 & 0.67 & 0.00 & 1.44 & 0.00 & 0.55 \\
\hline F (Fluoride) $m g / L$ & 550 & 0.03 & 18.54 & 0.26 & 141.11 & 0.28 & 156.20 & 0.15 & 84.52 \\
\hline Mn (Manganese) $m g / L$ & 797 & 0.06 & 45.08 & 4.96 & 3956.93 & 4.82 & 3845.08 & 2.93 & 2338.42 \\
\hline$N i(N i c k e l) m g / L$ & 993 & 0.01 & 5.38 & 0.04 & 35.00 & 0.02 & 15.46 & 0.02 & 16.85 \\
\hline $\mathrm{Pb}($ Lead $) m g / L$ & 1531 & 0.003 & 5.31 & 0.00 & 1.39 & 0.00 & 1.16 & 0.00 & 0.83 \\
\hline \multirow[t]{2}{*}{$\mathrm{Zn}(\mathrm{Zinc}) m g / L$} & 913 & 0.14 & 126.65 & 0.02 & 14.25 & 0.01 & 7.46 & 0.01 & 8.01 \\
\hline & TETI & & - 841 & & - 5412 & & . 5360 & & - 3591 \\
\hline
\end{tabular}

TETI indicates that manganese and potassium had the highest impact on the toxicological profiles of the polluted waters (G1, G2 and SS-D) with a total score above 2000, according to the ATSDR assessment, followed by ammonium, nitrate and aluminum [43]. Regarding SS-U water samples, nitrate was the most important constituent in terms of water quality concerns, followed by potassium, aluminum and zinc. G1 had the highest index value followed by G2 and SS-D, which clearly demonstrates the impact of mine activities on the water environment, where higher TETI values represent lower quality.

The evaluation of these three selected indices $\left(\mathrm{WQI}_{\mathrm{A}}, \mathrm{CI}\right.$ and TETI) highlights the coal mine inputs of metals and other pollutants in the study area. Although the three indices specify similar levels of contamination, their outcomes regarding the most important constituents are not uniform.

For example, for TETI calculation, potassium had a high impact with a total score 5-11 times higher than in SS-U. However, it is not considered in FAO or any international guideline for restriction on use purposes, hence it is not accounted for either the $\mathrm{WQI}_{\mathrm{A}}$ or $\mathrm{CI}$ indices. The same occurs regarding ammonia.

These findings clearly highlight the limitations of each index and of the international water quality guidelines that are, firstly, non-standardized between different countries and, secondly, do not provide guidelines for a number of pollutants of importance for specific matrices as is the case of coal mine effluents.

\subsection{PAH Analyses}

Regarding PAHs, analyses were performed in six campaigns (April 2017, September 2017, December 2017, November 2018, February 2019 and May 2019). According to the ring numbers, PAHs can be classified into three classes: 2-3 rings, 4 rings, and 5-6 rings composition, which represent low, medium, and high molecular weight hydrocarbons, respectively.

PAHs were detected in water samples at very low concentrations, with prevalence of low molecular weight compounds, with average concentration percentages that varied from $62 \%$ to $80 \%$, which indicate a petrogenic origin consistent with the water circulation through the coal bearing rocks in the mine [53] (Figure 7). 


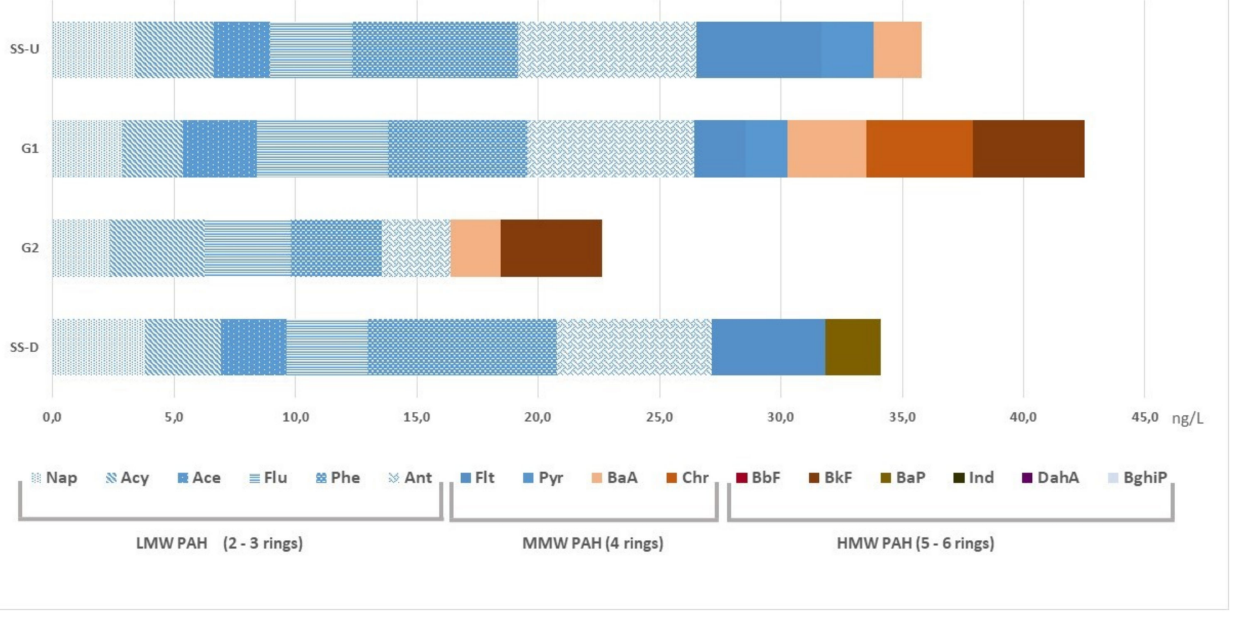

Figure 7. Composite model and average concentrations of PAHs in the studied samples.

The highest average concentration was detected in G1 (42.5 ng/L). SS-U and SS-D showed similar values of 35.8 and $34.1 \mathrm{ng} / \mathrm{L}$, respectively.

The carcinogenic PAHs (BaA, Chr, BbF, BkF, BaP, InP, and DahA) were detected mostly in G1 and G2, accounting for $28.8 \%$ and $27.6 \%$ of the total average concentration of 16 PAHs, in contrast to $5.6 \%$ and $6.7 \%$ found in SS-U and SS-D, being the main components in mine effluents the $\mathrm{BaA}$ and the BkF. The carcinogenic PAHs are high-ring PAHs, i.e., 4-6 ring, which is related to the degree of coal maturation [47].

PAHs are of high environmental and human health concern, as they are toxic and persistent in the environment, susceptible to long-range atmospheric transport, and able to bioaccumulate. The uptake of PAHs by plants is important when considering their transfer from soils and water into the food chain. Recent studies also demonstrate that PAHs-metal co-contamination also alters PAHs uptake, attributing to the metal-soil or metal-root interactions [54].

As food chain is the most important pathway for pollutants' entry into the human body, the uptake of carcinogenic PAHs and heavy metals through soil-to-root system and their translocation/accumulation in plant tissues is very important, particularly for food crops cultivated on non-treated wastewater-irrigated soils, as is the case.

\section{Conclusions}

This study points out the suitability of the coal mining effluents and the polluted surface water for irrigation purposes in São Pedro da Cova abandoned coalfield. The results allow proposing a cost-effective assessment methodology adjusted to specific problems of the water, minimize pollution of natural watercourses and soils and increase the potential of use of these effluents.

The evaluation of the use of mining effluents for irrigation can be an issue as specific water quality guidelines or legislation does not exist, and several dangerous chemicals are not included in routine water quality assays. In an attempt to standardize decision-making regarding irrigation with mining effluents, the criteria and data have been combined in user-friendly indices, which could assist in the practical implementation of mining effluents irrigation control plans as part of optimal mine-water management and reuse strategy. Eighteen parameters including selected anions, cations and trace elements were chosen after an exhaustive analysis and were used for water quality indices calculation. Source specific water quality indices are a very helpful tool to represent water quality in a simple and understandable manner, minimizing the data volume to a great extent and simplifying the expression of water quality status, giving efficiently the overall water quality of a specific area and for a specific use. 
Results revealed that samples associated with mining activities have unacceptable index values due mainly to the high concentration of iron, manganese, bicarbonates, magnesium and potassium, and are not suitable for irrigation. $\mathrm{WQI}_{\mathrm{A}}$ indicated an overall Poor/Very Poor quality status, which is in accordance with the level of contamination (CI) of these waters. The TETI index, which only reflects the elemental toxicological impact of the waters, not considering other fundamental water quality parameters, indicated that the impacted water samples had higher index values, and manganese had the highest impact on the toxicological profiles, also showing the influence of coal activities on surface water quality. Risks to human health also arise from water pollution by organic substances such as PAHs with several carcinogenic compounds detected in G1 and G2. Levels in the water collected upstream from mine drainage points are within acceptable range for irrigation.

Scientific community and local authorities of mine areas are committed to mitigating the effects of past actions through the development of better management strategies for reducing environmental and health impacts in the mining area. The understanding of the mine water chemistry is fundamental for the design of an effective treatment system. Simple passive treatments could be an option for the contaminated drainage at this abandoned mine site according to Robert Hedin el al. 2013 (Effective Passive Treatment of Coal Mine Drainage. Robert Hedin, Ted Weaver, Neil Wolf, George Watzalaf. Paper presented at the 35th Annual National Association of Abandoned Mine Land Programs Conference, 2013). If properly designed, constructed and maintained, passive systems provide highly reliable treatment at a fraction of the cost of active alternatives.

As the overall quality of groundwater from mine drainage galleries revealed contamination, it is very important to raise awareness for rapid intervention in the area, since the mine is located near a population center and social infrastructures, as well as to mitigate the pollution on adjacent agricultural lands. Despite the evident deleterious impact for local communities, the health effects of mine drainage remain neglected in research and policy arenas, mainly because of the lack of documented evidence. Such communities suffer the effects of mine drainage principally through a perpetual risk posed by water pollution. This project intended to study the impact of mine drainage contamination towards an investment in temporary to long-term solutions, in order to reduce the risks caused by mining externalities.

Author Contributions: Conceptualization, C.M.; methodology, C.M., A.M., J.E.M.; validation, C.M., J.E.M.; formal analysis, C.M., A.M., J.E.M.; investigation, C.M., J.E.M., V.M., P.S., J.R., J.R.R., A.M. and D.F.; resources, J.E.M., C.M., D.F.; writing-original draft preparation, C.M., J.E.M., A.M., P.S., J.R.; writing-review and editing, C.M., J.E.M., A.M.; supervision, C.M., J.E.M., D.F.; project administration, D.F.; funding acquisition, D.F. All authors have read and agreed to the published version of the manuscript.

Funding: This work was supported by the project CoalMine-Coal mining wastes: assessment, monitoring and reclamation of environmental impacts through remote sensing and geostatistical analysis-financed by the Portuguese Science and Technology Foundation, FCT, call AAC ${ }^{\circ}$ 02/SAICT/2017 (POCI-01-0145-FEDER-030138) and framed within the activities of the ICT (Ref. UIDB/04683/2020).

Institutional Review Board Statement: Not applicable.

Informed Consent Statement: Not applicable.

Data Availability Statement: The data supporting the findings of this study are available within the article.

Acknowledgments: The authors acknowledge the Mining Museum of São Pedro da Cova for the permission to use the photograph from Figure 1a. This work received support and help from the UID/QUI/50006/2020 with funding from FCT/MCTES through national funds.

Conflicts of Interest: The authors declare no conflict of interest. 


\section{References}

1. Mahato, M.K.; Singh, A.K.; Singh, G.; Mishra, L.P. Impacts of coal mine water and Damodar River water irrigation on soil and maize (Zea mays L.) in a coalfield area of Damodar Valley, India. Arch. Agric. Environ. Sci. 2017, 2, 293-297. [CrossRef]

2. Bott, T.L.; Jackson, J.K.; McTammany, M.E.; Newbold, J.D.; Rier, S.T.; Sweeney, B.W.; Battle, J.M. Abandoned coal mine drainage and its remediation: Impacts on stream ecosystem structure and function. Ecol. Appl. 2012, 22, 2144-2163. [CrossRef] [PubMed]

3. Johnston, D.; Potter, H.; Jones, C.; Rolley, S.; Watson, I.; Pritchard, J. Abandoned Mines and the Water Environment; Environment Agency: Bristol, UK, 2008; p. 31.

4. Tiwary, R.K. Environmental Impact of Coal Mining on Water Regime and Its Management. Water Air Soil Pollut. 2001, 132, 185-199. [CrossRef]

5. Lemos de Sousa, M.J.; Wagner, R.H. General Description of the Terrestrial Carboniferous Basins in Portugal and History of Investigations. In The Carboniferous of Portugal. Memórias dos Serviços Geológicos de Portugal; Lemos de Sousa, M.J., Oliveira, J.T., Eds.; Direção Geral de Geologia e Minas: Lisboa, Portugal, 1983; Volume 29, pp. 117-126.

6. Wagner, R.H.; Lemos de Sousa, M.J. The Carboniferous Megafloras of Portugal-A revision of identifications and discussion of stratigraphic ages. In The Carboniferous of Portugal. Memórias dos Serviços Geológicos de Portugal; Lemos de Sousa, M.J., Oliveira, J.T., Eds.; Direção Geral de Geologia e Minas: Lisboa, Portugal, 1983; Volume 29, pp. 127-152.

7. Eagar, R.M.C. The non marine bivalve fauna of the Stephanian C of North Portugal. In The Carboniferous of Portugal. Memórias dos Serviços Geológicos de Portugal; Sousa, M.J.L., Oliveira, J.T., Eds.; Direção Geral de Geologia e Minas: Lisboa, Portugal, 1983; Volume 29, pp. 179-185.

8. Fernandes, J.P.; Pinto de Jesus, A.; Teixeira, F.; Sousa, M.J.L. First palynological results in the Douro Carboniferous Basin (NW of Portugal). In Proceedings of XIII Jornadas de Paleontologia "Fósiles de Galicia" y V Reunión Internacional Proyecto 351 PICG "Paleozoico Inferior del Noroeste de Gondowana"; Sociedade Espanola de Paleontologia: Coruna, Spain, 1997; pp. $176-179$.

9. Custódio, J. Museum of Coal \& Mines of Pejão; Museum Programme: Castelo de Paiva, Portugal, 2004.

10. Pinto de Jesus, A. Sedimentary and tectonic evolution of the Douro Coalfield Basin (lower Stephanian C, NW Portugal). Cad. Lab. Xeolóxico Laxe 2003, 28, 107-125.

11. HLPE. Water for food security and nutrition. In A Report by the High Level Panel of Experts on Food Security and Nutrition of the Committee on World Food Security; Food and Agriculture Organization of the United Nations: Rome, Italy, 2015.

12. Pescod, M.B. Wastewater Treatment and Use in Agriculture - FAO Irrigation and Drainage Paper 47; FAO: Rome, Italy, 1992.

13. Al-Hwaiti, M.S.; Brumsack, H.J.; Schnetger, B. Suitability assessment of phosphate mine waste water for agricultural irrigation: An example from Eshidiya Mines, South Jordan. Environ. Earth Sci. 2016, 75, 276. [CrossRef]

14. Müller, K.; Cornel, P. Setting water quality criteria for agricultural water reuse purposes. J. Water Reuse Desalin. 2016, 7, 121-135. [CrossRef]

15. Jeong, H.; Kim, H.; Jang, T. Irrigation Water Quality Standards for Indirect Wastewater Reuse in Agriculture: A Contribution toward Sustainable Wastewater Reuse in South Korea. Water 2016, 8, 169. [CrossRef]

16. Alobaidy, A.; Al-Sameraiy, M.; Kadhem, A.; Majeed, A. Evaluation of treated municipal wastewater quality for irrigation. J. Environ. Prot. 2010, 1, 216-225. [CrossRef]

17. Abdul-Rahman, S.; Saoud, I.P.; Owaied, M.K.; Holail, H.; Farajalla, N.; Haidar, M.; Ghanawi, J. Improving Water Use Efficiency in Semi-Arid Regions through Integrated Aquaculture/Agriculture. J. Appl. Aquac. 2011, 23, 212-230. [CrossRef]

18. Ayers, R.S.; Westcot, D.W. Water quality for agriculture. In FAO Irrigation and Drainage Paper Rev. 1; FAO: Rome, Italy, 1994.

19. Alves, M.T.R.; Teresa, F.B.; Nabout, J.C. A global scientific literature of research on water quality indices: Trends, biases and future directions. Acta Limnol. Bras. 2014, 26, 245-253. [CrossRef]

20. Kachroud, M.; Trolard, F.; Kefi, M.; Jebari, S.; Bourrié, G. Water Quality Indices: Challenges and Application Limits in the Literature. Water 2019, 11, 361. [CrossRef]

21. Poonam, T.; Tanushree, B.; Sukalyan, C. Water Quality Indices- Important Tools for Water Quality Assessment: A Review. Int. J. Adv. Chem. 2015, 1, 15-29.

22. Horton, R.K. An index number system for rating water quality. J. Water Pollut. Control Fed. 1965, 37, 300-306.

23. Abbasi, T.; Abbasi, S. Water Quality Indices; Elsevier: Amsterdam, The Netherlands, 2012.

24. Misaghi, F.; Delgosha, F.; Razzaghmanesh, M.; Myers, B. Introducing a water quality index for assessing water for irrigation purposes: A case study of the Ghezel Ozan River. Sci. Total Environ. 2017, 589, 107-116. [CrossRef]

25. Cude, C.G. Oregon water quality index a tool for evaluating water quality management effectiveness. J. Am. Water Resour. Assoc. 2001, 37, 125-137. [CrossRef]

26. Backman, B.; Bodiš, D.; Lahermo, P.; Rapant, S.; Tarvainen, T. Application of a groundwater contamination index in Finland and Slovakia. Environ. Geol. 1998, 36, 55-64. [CrossRef]

27. Biswas, P.K.; Uddin, N.; Alam, S.; -Us-Sakib, T.; Sultana, S.; Ahmed, T. Evaluation of Heavy Metal Pollution Indices in Irrigation and Drinking Water Systems of Barapukuria Coal Mine Area, Bangladesh. Am. J. Water Res. 2017, 5, $146-151$.

28. Ali, A.; Strezov, V.; Davies, P.; Wright, I. Environmental impact of coal mining and coal seam gas production on surface water quality in the Sydney basin, Australia. Environ. Monit. Assess. 2017, 189, 408. [CrossRef]

29. EFSA. Polycyclic Aromatic Hydrocarbons in Food-Scientific Opinion of the Panel on Contaminants in the Food Chain. EFSA J. 2008, 6, 724. [CrossRef]

30. Rodríguez-Eugenio, N.; McLaughlin, M.; Pennock, D. Soil Pollution, A Hidden Reality; FAO: Rome, Italy, 2018. 
31. INE. Censos 2011 Resultados Definitivos_Portugal; Instituto Nacional de Estatística, I.P.: Lisbon, Portugal, 2012.

32. Julivert, M.; Fontboté, J.M.; Ribeiro, A.; Conde, L. Mapa Tectónico de la Península Ibérica y Baleares; IGME-Instituto Geológico y Minero de España: Madrid, Spain, 1974.

33. Medeiros, A.; Pereira, E.; Moreira, A. Notícia Explicativa da Folha 9-D (Penafiel) da Carta Geológica de Portugal à Escala 1:50 000; Serviços Geológicos de Portugal: Lisbon, Portugal, 1980.

34. Peel, M.C.; Finlayson, B.L.; McMahon, T.A. Updated world map of the Köppen-Geiger climate classification. Hydrol. Earth Syst. Sci. 2007, 11, 1633-1644. [CrossRef]

35. AEMET-IM. Atlas Climático Ibérico. Temperatura do Ar e Precipitação (1971-2000); Departamento de Producción da Agência Estatal de Meteorologia de Espanha (Área de Climatología y Aplicaciones Operativas) e Departamento de Meteorologia e Clima (Divisão de Observação Meteorológica e Clima), do Instituto de Meteorologia: Lisboa, Portugal, 2011.

36. ISO. ISO 5667-3:2018-Water Quality—Sampling_Part 3: Preservation and Handling of Water Samples, ISO: Geneva, Switzerland, 2018.

37. Rice, E.W.; Baird, R.B.; Eaton, A.D. Standard Methods for the Examination of Water and Wastewater, 23rd ed.; American Public Health Association: Washington, DC, USA, 2017.

38. Rodier, J.; Legube, B.; Merlet, N. L'analyse de l'eau, 10th ed.; Dunod: Paris, France, 2016.

39. Borges, B.; Armindo, M.; Ferreira, I.M.P.L.V.O.; Mansilha, C. Dispersive liquid-liquid microextraction for the simultaneous determination of parent and nitrated polycyclic aromatic hydrocarbons in water samples. Acta Chromatogr. 2018, 30, 119-126. [CrossRef]

40. Richards, L.A. Diagnosis and Improvement of Saline and Alkali Soils. Agricultural Handbook 60; United States Department of Agriculture: Washington, DC, USA, 1954.

41. Sawyer, C.N. Chemistry of Sanitary Engineers, 2nd ed.; McGraw-Hill: New York, NY, USA, 1967.

42. Doneen, L.D. Notes on Water Quality in Agriculture; Department of Water Science and Engineering, University of California, Davis: Oakland, CA, USA, 1964.

43. Oni, O.; Fasakin, O. The use of water quality index method to determine the potability of surface water and groundwater in the vicinity of a municipal solid waste dumpsite in Nigeria. Am. J. Eng. Res. 2016, 5, 96-101.

44. Tyagi, S.; Sharma, B.; Singh, P.; Dobhal, R. Water Quality Assessment in Terms of Water Quality Index. Am. J. Water Res. 2013, 1, 34-38. [CrossRef]

45. Chatterjee, C.; Raziuddin, M. Determination of water quality index (WQI) of a degraded river in Asansol Industrial area, P.O. Raniganj, District Burdwan, West Bengal. Nat. Environ. Pollut. Technol. 2002, 1, 181-189.

46. ATSDR. Priority List of Hazardous Substances; Agency for Toxic Substances and Disease Registry: Division of Toxicology and Human Health Sciences: Atlanta, GA, USA, 2019.

47. Chen, D.; Feng, Q.; Liang, H.; Gao, B.; Alam, E. Distribution characteristics and ecological risk assessment of polycyclic aromatic hydrocarbons (PAHs) in underground coal mining environment of Xuzhou. Hum. Ecol. Risk Assess. 2019, 25, 1564-1578. [CrossRef]

48. Singh, G. Impact of coal mining on mine water quality. Int. J. Mine Water 1988, 7, 49-59. [CrossRef]

49. EPA. Guidelines for Water Reuse; U.S. Environmental Protection Agency: Washington, DC, USA, 2012.

50. Rengasamy, P.; Marchuk, A. Cation ratio of soil structural stability (CROSS). Soil Res. 2011, 49, 280-285. [CrossRef]

51. Oster, J.D.; Sposito, G.; Smith, C.J. Accounting for potassium and magnesium in irrigation water quality assessment. Calif. Agric. 2016, 70, 71-76. [CrossRef]

52. Climatological Bulletin. Available online: https://www.ipma.pt/pt/publicacoes/boletins.jsp (accessed on 6 April 2021).

53. Stout, S.A.; Emsbo-Mattingly, S.D. Concentration and character of PAHs and other hydrocarbons in coals of varying rankImplications for environmental studies of soils and sediments containing particulate coal. Org. Geochem. 2008, 39, 801-819. [CrossRef]

54. Zhang, S.; Yao, H.; Lu, Y.; Yu, X.; Wang, J.; Sun, S.; Liu, M.; Li, D.; Li, Y.-F.; Zhang, D. Uptake and translocation of polycyclic aromatic hydrocarbons (PAHs) and heavy metals by maize from soil irrigated with wastewater. Sci. Rep. 2017, 7, 12165. [CrossRef] 